University of Michigan Law School University of Michigan Law School Scholarship Repository

1990

\title{
Stalking the Squeeze: Understanding Commodities Market Manipulation
}

Richard D. Friedman

University of Michigan Law School, rdfrdman@umich.edu

Available at: https://repository.law.umich.edu/articles/180

Follow this and additional works at: https://repository.law.umich.edu/articles

Part of the Commercial Law Commons, and the Public Law and Legal Theory Commons

Recommended Citation

Friedman, Richard D. "Stalking the Squeeze: Understanding Commodities Market Manipulation." Mich. L. Rev. 89 (1990): 30-68.

This Article is brought to you for free and open access by the Faculty Scholarship at University of Michigan Law School Scholarship Repository. It has been accepted for inclusion in Articles by an authorized administrator of University of Michigan Law School Scholarship Repository. For more information, please contact mlaw.repository@umich.edu. 


\title{
STALKING THE SQUEEZE: UNDERSTANDING COMMODITIES MARKET MANIPULATION
}

\author{
Richard D. Friedman*
}

Commodities manipulations often have spectacular results. Not all dramatic upheavals in the commodities markets result from manipulation, however; indeed, sometimes when prices rise sharply the market is performing one of its most important functions, cushioning the impact of external forces that might otherwise have been far more disruptive. ${ }^{1}$ Thus, attempting to discern the line between a manipulated

* Professor of Law, University of Michigan. B.A. 1973, J.D. 1976, Harvard University; D. Phil. 1979, Christ Church, Oxford, England. - Ed. My thanks to Charlie Bieneman and Peter Gold for extremely able research assistance and to George Davidson, Merritt Fox, Jerry Markham, Fred Schauer, Joel Seligman, and James J. White for helpful comments.

1. A recent episode, out of which litigation is currently pending, illustrates how the same conduct might be characterized as manipulative or as perfectly proper market behavior. An Italian firm, Ferruzzi Finanziaria S.p.A, was long about 23 million bushels in the July 1989 soybean contract on the Chicago Board of Trade (CBOT) while less than 13 million bushels were readily deliverable. The CBOT forced large long traders, including Ferruzzi, to reduce their positions, resulting in a sharp drop in soybean prices and costing Ferruzzi millions of dollars. The CBOT has since begun disciplinary proceedings against Ferruzzi on charges that the company attempted to corner the market. Ferruzzi, however, has asserted that its conduct was entirely legitimate because it was attempting to meet the needs of one of its subsidiaries, a manufacturer of soybean products; indeed, Ferruzzi has claimed that the CBOT order was itself a manipulative order to drive prices down, thus favoring six of the CBOT's directors, who held short positions at the time. See, e.g., Markham, The Manipulation of Commodity Futures Prices - The Unprosecutable Crime, 7 YALE J. on REg. (forthcoming 1990); Ferruzzi Loses Court Request, N.Y. Times, Sept. 15, 1990, § 1, at 32, col. 4; Greising \& Rossant, Why the Pits Are Sick Over Soybeans, Bus. WK., July 31, 1989, at 76; CBOT Chief Answers to Iowa Soybean Farmers, Chi. Trib., July 22, 1989, at 1, col. 2; U.S. Agency Forced Ferruzzi to Trim Soybean Holdings, L.A. Times, July 21,1989 , pt. 4, at 1, col. 2.

The Hunt family of Texas was involved in an earlier alleged squeeze of the CBOT soybean market, this one involving the May 1977 contract. See Commodity Futures Trading Commn. v. Hunt, 591 F.2d 1211 (7th Cir. 1979). Collectively, the Hunts held a long position of about 32.5 million bushels, far more than both the deliverable supply at that time, about 10 million bushels, and the speculative position limits imposed by the Commodity Futures Trading Commission (CFTC). See Reauthorization of the Commodity Futures Trading Commission: Hearings Before the Subcomm. on Agricultural Research and Gen. Legislation of the Comm. on Agric., Nutrition, and Forestry, 95th Cong., 2d Sess. 216 (1978) (pt. II); Markham, supra. Notwithstanding the Hunts' protests that they were not acting in unison, they ultimately agreed with the CFTC to pay $\$ 500,000$ in civil sanctions - the largest in history - and to abstain from soybean trading for two years. Hunts Paying Civil Penalties on Soybeans, N.Y. Times, July 22, 1981, at D14, col. 6.

The Hunts were also involved in what is probably the best-known recent case of alleged manipulation, the silver boom and bust of 1979-1980. The price of silver futures had been relatively stable at about \$6 per ounce from 1974 through 1978, but in 1979 began to rise sharply. The rise accelerated through the last part of the year, and on January 17, 1980 peaked at about $\$ 50$ per ounce. Then the tumble began, and by March 17, 1980 the price had fallen back to $\$ 10.80$ per ounce. See, e.g., Minpeco, S.A. v. Hunt, 693 F. Supp. 58, 60 (S.D.N.Y. 1988); Knight \& Rowe, Jr., Hunt Brothers Thrill Ride in Silver Takes U.S. Close to Disaster, Wash. Post, Apr. 17,1980 , at G1. The episode spawned a massive web of litigation, centering on accusations that the Hunts and others manipulated the silver market. See, e.g., Minpeco, S.A. v. ContiCom- 
market and a properly functioning one is perhaps the most important question in commodities law, and certainly one of the most intriguing. Congress has been intent on preventing manipulation since the beginning of federal commodities regulation in the $1920 \mathrm{~s}^{2}$ yet courts, administrators, and academic commentators have failed to agree on a sensible approach to the basic question: What is manipulation? This article focuses on the most important type of manipulation,

modity Servs., Inc., 832 F.2d 739, 740 (2d Cir. 1987). (From 1980 to 1982, I participated actively in the representation of ContiCommodity Services, Inc., principally in matters arising out of the silver episode.)

For other incidents in which comers or squeezes were alleged, or in which a market appeared ripe for such manipulation, see In re Compania Salvadorena De Cafe [1982-1984 Transfer Binder] Comm. Fut. L. Rep. (CCH) I 21,886 (Oct. 26, 1983) (holding that respondent manipulated the July 1977 coffee futures contract on the New York Coffee and Sugar Futures Exchange); H.R. REP. No. 565, 97th Cong., 2d Sess., pt. 1, at 71-73 (1982) (noting that four traders dominated the March 1979 CBOT wheat contract, which traded at an unusual differential to the May contract, and concluding that these traders could have manipulated the market had they chosen to but that the evidence of such manipulation "was not very strong"); In re Indiana Farm Bureau Coop. Assn., [1982-1984 Transfer Binder] Comm. Fut. L. Rep. (CCH) § 21,796 (Dec. 17, 1982) (rejecting allegation of manipulation of the July 1973 CBOT corn contract, notwithstanding extremely steep price rise on the last day of trading); In re Abrams, [1987-1990 Transfer Binder] Comm. Fut. L. Rep. (CCH) I 24,408 (Feb. 8, 1989) (initial decision) (rejecting allegation of attempted manipulation of September 1984 frozen orange juice concentrate contract on New York Cotton Exchange, even though the accused held a dominant long position and placed "scaled-up orders" to sell well over the market price, because trader, who had anticipated a shortage, was attempting to make legitimate speculative profits), interlocutory review denied, [1987-1990 Transfer Binder] Comm. Fut. L. Rep. (CCH) I 24,577 (Oct. 13, 1989); Apex Oil Co. v. DiMauro, 822 F.2d 246 (2d Cir. 1987) (reviewing grant of summary judgment, holding that evidence was sufficient with respect to certain alleged conspirators, but not with respect to others, to support a claim of manipulation of the February 1982 heating oil futures contract on the New York Mercantile Exchange); In re Cox, [1986-1987 Transfer Binder] Comm. Fut. L. Rep. (CCH) [ 23,876 (July 15, 1987) (rejecting a claim of manipulation of the May 1971 CBOT wheat contract, notwithstanding dominant position held by respondents and a large price rise on the final day of trading; shorts held accountable for failure to deliver), revg. [1982-1984 Transfer Binder] Comm. Fut. L. Rep. (CCH) II 21,767 (Jan. 3, 1983).

For a comprehensive survey of manipulation cases, see Markham, supra.

2. The first comprehensive federal regulation of futures trading, the Future Trading Act of 1921, focused on what it deemed excessive speculation, but it also authorized the Secretary of Agriculture to suspend the trading privileges of anyone "attempting to manipulate the market price of any grain." The Future Trading Act, Pub. L. No. 66, ch. 86, 42 Stat. 187, 189 (1921). That Act was held unconstitutional in Hill v. Wallace, 259 U.S. 44 (1922). It was promptly replaced, however, by the Grain Futures Act, Pub. L. No. 331, ch. 369, 42 Stat. 998, 1000 (1922), which contained essentially identical substantive terms but relied on the commerce power rather than the taxing power. In 1936, Congress enlarged the scope of the Act's coverage and renamed it the Commodity Exchange Act. Commodity Exchange Act, Pub. L. No. 675, ch. 545, 49 Stat. 1491 (1936) (codified as amended at 7 U.S.C. $\$ \S 1-26$ (1988)). In doing so, Congress for the first time made it a federal criminal violation to "manipulate or attempt to manipulate the price of any commodity in interstate commerce" or to "corner or attempt to corner any such commodity." Commodity Exchange Act $\S 116,49$ Stat. at 1501 (1936). These prohibitions remain intact today in the current code, 7 U.S.C. $\$ 13(b)$ (1988), and in recent years prevention of manipulation has become perhaps the principal focus of regulatory efforts. See S. REP. No. 1131, 93d Cong., 2d Sess. 21 (1974), reprinted in 1974 U.S. CODE CONG. \& ADMIN. News 5843, 5861 (Committee on Agriculture and Forestry Report on H.R. 13113) ("The proper regulatory function of an agency which regulates futures trading is to assure that the market is free of manipulation and other practices which prevent the market from being a true reflection of supply and demand."). 
and the most intractable to analyze - the squeeze. ${ }^{3}$ To get a first glimpse of the problem, consider the following hypothetical.

$A$ Hypothetical: A Squeeze or Ordinary Trading? Suppose that futures contracts in stringbeans are traded on the Fictitious National Stringbean Exchange (FNSE). Like other traditional futures contracts, these are standardized, bilateral executory contracts. ${ }^{4}$ They call for the seller to deliver a standardized quantity of a standardized type of stringbean at a specified delivery point during a specified period.

This precision makes liquidity practical. If a buyer and a seller both want to enter into a contract for June delivery, they need only bargain over price. Although they make their contract face to face, in open bidding on the floor of the exchange, they do not have to deal with each other afterwards. For every long (one who has bought futures contracts), there is one and only one short (one who has sold). The exchange's clearinghouse steps between the traders, taking the short position to every long and the long position to every short. If

3. Some discussions differentiate between a squeeze and a corner, with the distinction being that the corner, unlike the squeeze, requires domination of the market for the physical commodity. See, e.g., T. RUSSo, REgulation OF THE COMmOdITIES Futures aNd OPTIONS MARKETS \$ 12.10 (1983); Cargill, Inc. v. Hardin, 452 F.2d 1154, 1162 (8th Cir. 1971), cert. denied. 406 U.S. 932 (1972). As used by the Cargill court, the term squeeze refers to any situation in which "the open interest on the futures market is considerably in excess of the deliverable supplies," and is not necessarily manipulative. 452 F.2d at 1162 . The Cargill court reserves the term "intentional squeeze" for the situation in which a long manipulatively exploits a shortage of deliverable supplies. 452 F.2d at 1162 . As used in this article, the term squeeze indicates an act of manipulation; a shortage that is neither caused nor exploited manipulatively is not considered a squeeze. I do not distinguish between a squeeze and a corner, in part because I believe they represent essentially the same phenomenon. Simplifying somewhat, a long has power to squeeze the market if his futures position exceeds the deliverable supply in independent hands; it matters relatively little whether, or to what extent, the low level of independently held supply is explained by an extensive hoard of the physical commodity in the long's hands or by other causes. Furthermore, even if a squeezer does not begin with a significant holding of the physical commodity, he will almost always acquire one during the course of his squeeze, because the higher he drives the price the more the shorts will find it preferable to deliver rather than to liquidate.

This article does not discuss another category of manipulation, which might be called manipulation by misinformation, see infra note 15 and accompanying text. Ordinarily, I suspect, it is less difficult conceptually to recognize whether challenged conduct is manipulative in this way.

Nor does this article discuss the counterpart to a squeeze, in which a short futures trader delivers very large quantities on her contracts, thus driving the price down. Short manipulation of this sort, however, might be subject to analysis similar to that in this article: Whereas a squeeze is an attempt to exploit the vulnerability of the shorts arising from the unavailability of adequate deliverable supply, the short manipulation might be an attempt to exploit the vulnerability of longs arising from the unavailability of adequate facilities for handling deliveries.

4. Traditional contracts are those that, absent liquidation, call for actual delivery. I use the term to distinguish a newer form of contract that calls for settlement in cash; that is, at expiration, any unliquidated contracts are valued according to the level of some predetermined index. Cash-settlement contracts are not subject to the type of manipulation discussed in this article; on the other hand, they are not feasible for all commodities. See infra note 8.

For general descriptions of the mechanics of futures trading, see, e.g., 1 P. JoHNSON \& T. HAZEN, COMMODITIES Regulation $\$ 1.31$ (2d ed. 1988); T. HieronYMUS, ECONOMICS OF Futures Trading for Commercial and Personal Profit 43-46 (2d ed. 1977). 
later, say, the short decides that she ${ }^{5}$ would rather not deliver on her contract, she does not have to find the long with whom she originally dealt. Rather, all she must do is buy back a contract on the floor of the exchange, from any willing seller. Her purchase and sale cancel each other out; she has liquidated her position. If prices fell between her two transactions, so that she sold dear and bought cheap, she has made money. If prices rose, she has lost.

Most traders liquidate their positions before the contract expires. But not all do: a small number of longs will hold their positions to the end, standing for delivery and obligating themselves to pay the full price of the commodity, ${ }^{6}$ and an equal number of shorts will be obligated to make delivery. Usually delivery proceeds quite smoothly.

What good does this all do? For a few traders, the futures exchange provides a useful means of buying physical product. For many more, the exchange provides an important means of hedging against price changes in the physical product. If, for example, Processor buys a large stock of beans, she may be worried that the bottom will fall out of the beans market before she is ready to sell her finished product. Accordingly, she may go short in the futures market for an equal amount of beans. Assuming the futures and physicals prices move closely in tandem, she will recoup in the futures market any drop in physicals prices, because when she sells the physical beans she will liquidate her short futures position at a lower price. (If physicals prices soar, Processor's futures position will wipe out the windfall she would have had in the physicals market, but that is what a hedge is all about; she intends to make her profit on processing, not on commodity speculation.)

Many traders expect to use the market neither for delivery nor for hedging; rather, they are pure speculators. They are essential, too, for the market would not have sufficient liquidity without them. They help ensure that at any given time futures prices do not stray far from prices for similar physicals delivered at nearby places and times; if the prices do diverge, speculators rush to arbitrage the difference away. male.

5. I mean "he or she," of course, but for simplicity I will make all shorts female and all longs

6. At the time of contracting, traders, both long and short, are obligated to post a certain amount of funds as margin. This is not a down payment - sellers as well as buyers must post margin - but in essence a security bond to protect against adverse movements in price. As the market price changes from day to day, each trader's account is "marked to market" - that is, longs' accounts are increased to reflect price rises and decreased to reflect price falls, and shorts' accounts are adjusted in the opposite direction. If the value of the account falls below prescribed levels, the trader may receive a margin call - that is, be required to add funds to the account to prevent liquidation. Ordinarily, only if a buyer stands for delivery must he pay in the full price of his contract. 
Now suppose that trader Long controls a large share of the physical supply of stringbeans now available for delivery near the FNSE, and also a large long position in the expiring futures contract. Shortly before expiration of the contract, supplies are very tight, and the price rises sharply. Most other long traders liquidate their positions, providing only slight relief to the shorts, who are now effectively compelled either to satisfy their obligations by delivery or to deal with Long. Long nevertheless declines for an extended period to liquidate his futures position or to sell any of his physical supply; instead, knowing that if he does not liquidate promptly many of the shorts will deliver, he stands for delivery. At last, with prices continuing to soar and expiration of the contract nearing, Long begins to sell futures contracts. Long sells enough contracts at elevated prices so that none of the shorts default. After expiration of the contract, prices fall quickly, and some time afterwards Long sells off much of his remaining supply of physicals. Soon after that, Long is charged with manipulation.

Long may well deny that he did anything wrong. Indeed, he will likely contend that the shorts were at fault, for failing to move beans into position for delivery. He may argue that he simply anticipated an upward surge in the price of beans, and he should not be denied the rewards of, or be punished for, his prescience. Or he may assert that he had use for the physical beans and had wanted to take delivery of them; only a very sharp price rise changed his plans, and in doing so he was rather graciously letting the shorts off the hook.

This article addresses the perplexing and important problem of how to distinguish valid, large-scale trading activity from a squeeze. Part I analyzes and reformulates what I will call the price-impact test, according to which manipulation is conduct motivated by its impact on price. This test, I contend, states a necessary but not sufficient condition for characterizing conduct as a squeeze.

Part II offers a substantially different test, which I call the modified-sanctions approach. Under this approach, the price-impact test is used as a preliminary safe-harbor standard. The modified-sanctions approach goes further, however, recognizing that the essence of a squeeze is exploitation of the shorts' vulnerability to default. The only way to test for that is to determine what the price would be if the sanctions for default were limited to the ordinary measure of contract damages.

Part III then compares this new test to the classical approach used by courts and other decisionmakers in squeeze cases. Here I contend that the proposed test responds to the same factors as the classical approach, but in a far less wooden way that better accounts for and 
explains their significance. Decisionmakers feeling bound to follow the classical approach can nevertheless find enough play in its joints to adopt the test proposed here.

Finally, an Appendix offers an examination of the economics of the squeeze.

\section{The Price-Impact Analysis Examined AND REFORMULATED}

\section{A. The Perdue Formulation}

In a recent article titled Manipulation of Futures Markets: Redefining the Offense, ${ }^{7}$ Professor Wendy Collins Perdue has made a major stride toward understanding commodities manipulation. I essentially agree with, and so will not repeat, her careful demolition of prior analyses of the problem. ${ }^{8}$ Professor Perdue's contributions are not all negative: The approach she offers, I argue, is an important step in the right direction. But it is not an adequate solution.

Professor Perdue's analysis requires the factfinder to determine the answer to one basic question, easy enough to conceptualize however difficult it may be to answer in particular cases. Although her articulations of that question vary somewhat, ${ }^{9} \mathrm{I}$ think it is best phrased subjectively, something like this: Was the trader's conduct decisively

7. Perdue, Manipulation of Futures Markets: Redefining the Offense, 56 FORDHAM L. REV. 345 (1987).

8. George Davidson advances another argument, that the manipulation problem should be avoided by providing that futures contracts be settled in cash rather than by physical delivery that is, that at the close of trading any contract not offset be valued in cash according to the price of the actual commodity. Davidson, Squeezes and Corners: A Structural Approach, 40 Bus. LAw. 1283, 1297-98 (1985). Davidson may well be correct that cash settlement contracts should be favored where practical because, lacking a delivery requirement, they cannot be squeezed. Not all futures markets, however, can practically be settled in cash. Cash settlement requires that there be another market that yields "reliable market values" and is "reasonably protected from tampering (such as manipulation)." P. JOHNSON, FUTURES MARKETS: AN OVERVIEW OF THE AEI STUDIOS 3 (1986). Thus, futures contracts the value of which are keyed to broad-based stock indices can practically be settled in cash. The same is not true of, say, wheat contracts especially since, as Davidson acknowledges, much of the trading for the physical product takes place on the futures exchange itself. Id. at 1298. Davidson's suggestion, that the exchange "split the contract into a delivery contract and a nondelivery contract, closing out the nondelivery contract at the delivery contract price," id., appears to shift the problem without solving it; the delivery contract, it appears, would still be vulnerable to manipulation.

9. Three times Perdue gives the definition an identical objective phrasing; see Perdue, supra note 7 , at $348,393,401$; twice she gives what appears to be a subjective phrasing, see id. at 358 ("manipulation occurs when the trader's expectation of profit derives from his expectation that his transactions will affect the market"), 395-96 ("any conduct where the anticipated profitability of that conduct depends on its affecting the price of the commodity traded"); and at least once her phrasing is quite ambiguous, see id. at 400 ("conduct that appears uneconomic about a manipulative intent" establishes a prima facie case of manipulation; the burden then shifts to the defendant "to articulate a legitimate nonmanipulative reason for the conduct" by "proof that his conduct was economically rational even absent an effect on price"). 
motivated by the expectation that the conduct itself would affect the market price, in the sense that but for the expectation he would not have engaged in the conduct? ${ }^{10}$ If so, then according to Professor Perdue's analysis - which I will call the "price-impact test" - the trader is guilty of manipulation. ${ }^{11}$

As so understood, the price-impact test has great simplicity and elegance. Unlike the prevailing doctrine, ${ }^{12}$ it does not resort to a clumsy, multi-part formula, ${ }^{13}$ but instead asks a single question that seems intuitively to comport with our underlying notions of manipulation. Perhaps the problem of defining manipulation is not nearly so difficult as it seems; perhaps "conduct motivated by a desire to affect market price" is essentially what we mean by "manipulation," in a straightforward lexical sense, without the need to resort to fancy policy arguments. ${ }^{14}$ Perhaps such lexical equivalence is why the price-

10. There is a problem implicit in the "but for" language: Large-scale economic activity ordinarily does have a substantial price impact, and so it probably is not useful to imagine that the trader engaged in the conduct without anticipating the impact. In any case, we can usefully ask how the trader would have acted if he had disregarded the price impact. See infra note 58 and accompanying text.

This test is subjective because it asks whether the trader actually would have engaged in the activity but for the price expectation - not whether the activity would have been rational but for the expectation. In practical terms the subjective and objective tests are probably quite similar; evidence of subjective intent could be offered on the question of objective rationality, and vice versa. Of the two, though, the subjective test is preferable. To a large extent, commodities trading is idiosyncratic. As the term "manipulation" itself suggests, we do not castigate a trader for making a trade that others would find irrational, but only for attempting to profit by a wrongful method.

11. Throughout this article, I will speak of the alleged manipulator as being a single trader. It could, of course, be numerous traders acting collusively. See, e.g., note 1 supra (discussing Ferruzzi Finanziaria and the Hunt family).

12. See Part III infra.

13. Cf. Nagel, The Formulaic Constitution, 84 Mich. L. Rev. 165 (1985) (identifying and criticizing "a new style of opinion writing [in] constitutional exegesis [that] emphasizes formalized doctrine expressed in elaborately layered sets of 'texts' or 'prongs' or 'requirements' or 'standards' or 'hurdles' ").

14. Perdue is able to cite early statements by regulators assuming that manipulation occurs only when traders take actions to affect the market adversely. For example, the Grain Futures Administration described manipulators as a breed of professional speculators

who trade largely on the basis of mob psychology and faith in their ability through heavy trading to bring about temporary market conditions of which they may take advantage to make profits....

$\cdots$

... Instead of assuming a long or short position in the market, in the light of fundamental world conditions, their efforts were directed to creating a technically weak market condition, either buying the market into new high ground or selling it down and later taking advantage of its disturbed condition.

Fluctuations in Wheat Futures: Letter from the Secretary of Agriculture Transmitting, in Response to Senate Resolution No. 222, of June 9, 1926, a Report of The Grain Futures Administration Relative to the Extreme Fluctuation in the Price of Wheat Futures During the Early Part of 1925, at 5 (June 28, 1926), cited in Perdue, supra note 7, at $358 \mathrm{n} .80$.

The Chairman of the House Committee on Agriculture quoted President Hoover describing manipulation by a short trader as activity that has but "one purpose, and that is to depress 
impact test has the breadth that Perdue claims for it, applying to what might be called manipulation by misinformation ${ }^{15}$ as well as to corners and squeezes.

\section{B. Failure To Act as the Essence of Manipulation: $A$ Reformulation of the Price-Impact Test}

Simplicity and elegance are much to be desired. More critical, however, is whether, at least most of the time, the price-impact test leads to sensible results. In considering this question, I believe we must add one interpretive caution, not directly addressed by Professor Perdue, but essential to the analysis: "Conduct" must be understood to include a failure to act.

Even if a trader - such as our old acquaintance Long - builds up a long position over time with the anticipation that he will eventually squeeze the market, it is not primarily his purchases that cause the market movement from which he hopes to profit; indeed, the early purchases make the later purchases more expensive. ${ }^{16}$ And at the other end, when Long reaps the rewards of his scheme by selling off his position, his sales do not move the market in the direction he wants: Each sale is a partial abandonment of Long's power over the market, and if anything is likely to lower the price for subsequent sales. It is the failure to act in between - the refusal to liquidate until the last minute, even though the shorts have no other way out - that drives the market in the direction he wants.

Moreover, Long might in perfect innocence take action that later, as the futures contract nears expiration, puts him in a position to squeeze the market. He then could exploit his position passively by refusing to liquidate, for no reason other than that the refusal will cause the price to soar. Suppose, for example, that Long honestly took

prices." Commodity Short Selling: Hearings Before the House Comm. on Agriculture, 72d Cong., 1st Sess. 219 (1932), quoted in Perdue, supra note 7, at 355.

15. See, e.g., In re David G. Henner, 30 Agric. Dec. 1151, 1182, 1188 (1971) (After purchasing all available egg contracts in the last few seconds of trading, trader bid for one more just as the final bell rang, apparently in an effort to establish a high closing price and so give an impression of an upward price trend.); In re Howard Randolph, 21 Agric. Dec. 219, 222-23 (1962) (Trader, having made a sale of eggs with the price to be based on the spot price on the day of delivery, artificially bid up the spot price.).

16. True, once the long builds up his position, he may relish the upward price impact that further purchases will have. But those purchases also mean he will have a larger position to unload in the end, and he may find that he cannot sell the incremental quantity at the same elevated price at which he bought it. I have heard it said in this context that it is not always possible to go out by the same door through which one comes in.

This does not, of course, mean that the timing of purchases is irrelevant in determining whether manipulation occurred. Increasing one's long position after learning of market congestion may be evidence of manipulative intent. In re Indiana Farm Bureau Coop. Assn., [19821984 Transfer Binder] Comm. Fut. L. Rep. (CCH) \ 21,796, at 27,289 n.12 (Dec. 17, 1982). 
a large long futures position to hedge a short position in the physicals market for stringbeans. At some point, Long might realize that the futures position is more valuable for squeezing than for hedging. Suppose one of the shorts offers to sell him in an off-exchange deal some stringbeans that, because they are located a considerable distance from the prescribed delivery point, do not conform to the futures contract but would satisfy his need for physicals even better than conforming beans would. If Long refuses to deal at all for the nonconforming beans, or pays cash for them and then delays in liquidating the long position that was supposedly held as a hedge, he probably is abusing his innocently gained power.

The price-impact test must therefore be understood to include failures to act as well as affirmative conduct. As so understood, the test covers manipulation of the types discussed in the preceding two paragraphs. Indeed, under this broad construction, the price-impact identifies a necessary condition for a squeeze: If a long trader acts exactly as he would if he did not expect his conduct to have any price impact, his conduct should be considered ordinary trading activity, and so not manipulative.

There is, however, a perplexing ambiguity in asking whether the trader acted exactly as he would have if he did not expect his conduct to have any price impact. Impact in this sense must be a relative term. That is, saying that a course of conduct has no price impact can only mean that, given that course of conduct, the price is the same as it would have been if some alternative course or courses of conduct had been followed. But what alternative, or alternatives, do we use to measure? If the challenged conduct were an overt act, perhaps the measuring stick would be the absence of that conduct, although even that might be ambiguous. In the case now being considered, the ambiguity is more pressing, because the essence of the challenged conduct itself is a failure to act - the long trader's withholding contracts and physical product from the market.

The best approach to the problem, I believe, is to ask whether there is any less restrictive course of conduct that the trader would have found preferable to his actual conduct if the actual conduct had in fact led to the same price that this less restrictive course would have. There may be, however, an air of unreality about asking this question: We cannot hypothesize that the trader's course of conduct would lead to a price substantially different from the one it actually did lead to unless we also hypothesize a change in the facts of the situation, such as the extent of available supply, or in economic reality. This perhaps is endemic to the nature of causal inquiries: They may ask us to examine 
the consequences of counterfactual situations, and in doing so to assume a change in the factor under examination (here, the price resulting from a given course of conduct), but not in others. ${ }^{17}$ I will return to this problem in Part III.

\section{The Reformulated Test Avoided and Challenged}

Long might offer at least three theories to show that the price impact of his conduct was not a decisive factor behind his decision. First, he may contend that in fact the conduct had no more than a trivial price impact, because it was small on the scale of the entire market. This would work if Long's holdings were small. But because passivity is a form of conduct, a trader who withholds a large amount of the commodity from the market usually must be regarded as having had a significant price impact. An alternative course of conduct selling the product - would presumably have led to a substantially lower price.

Second, Long may contend that his conduct was based on his hopes of profiting from a price rise that he anticipated. ${ }^{18} \mathrm{He}$ may argue that, even if the very conduct of withdrawing or withholding product from the market contributed to the price rise, this impact was not a precondition to his conduct. But a trader who already has large holdings may again have difficulty making this argument convincingly: Unless he can show that he believed that the market was undervaluing the commodity radically, he will probably not be able to prove that he anticipated the price would rise even if he sold off his holdings. Thus, the anticipated price rise that justified his decision not to sell was probably caused in decisive measure by that very decision. ${ }^{19}$

Finally, and probably most plausibly for a large trader, he might show that he actually needed the commodity and placed a high value on using it. ${ }^{20}$ If the product was worth more in Long's hands than the price he could get for it on the market, then he was warranted in with-

17. See generally Wright, Causation in Tort Law, 73 CALIF. L. REv. 1735, 1777-81 (1985).

18. "Simply acting on one's predictions and evaluations of publicly available information cannot be considered manipulative, since that is what speculators are all about." In re Abrams, [1987-1990 Transfer Binder] Comm. Fut. L. Rep. (CCH) I 24,408, at 35,785 (Feb. 8, 1989).

19. A trader may be able to persuade the factfinder that he made additional futures purchases because he anticipated that the price would rise independently of his action, and that his purchase was a large one because he had confidence in his prediction. (The Administrative Law Judge in Abrams, supra note 18, appears to have accepted this argument with respect to late purchases by a dominant long.) Nevertheless, as the price rises, at least in part because of the long's acquisition, it becomes more and more difficult for him to show that it would continue to make sense for him to acquire and retain the commodity even if he did not expect the price to be continued to be supported by his holdings.

20. Note, for example, that Ferruzzi, S.p.A., is making this contention in its dispute concerning the July 1989 CBOT soybean market. See supra note 1. 
holding it, even without taking into account the upward pressure this would have on price. Indeed, he may go beyond denying that the price rise was a factor causing him to withhold the product from the market; he may affirmatively contend that he retained the product despite the price rise, which raised the implicit cost of doing so.

If Long prevails on any of these contentions, then the price-impact test is not met, and his conduct must be considered nonmanipulative. If, however, Long loses on each of these contentions, it will appear that the anticipated price impact was a but-for cause of his conduct. Yet that does not inevitably condemn the conduct as manipulative. Having recognized that the price-impact test applies to passive conduct, we must now recognize that the test cannot be a sufficient condition for manipulation.

As Perdue acknowledges, "For traders to try to sell at the highest price they can or to 'hold out' for a more advantageous price represents normal activity in the futures market as well as all other markets."21 In any negotiation, a trader, even though intent on selling, may hold out for a time, simply in the expectation that by doing so he will cause potential buyers to raise their bids; but for that expectation, the seller would make a deal earlier. As we have just seen, a potential seller may of course hold out in hopes of better market conditions, ${ }^{22}$ but that is not the point here; rather, the focus is on the seller who does not expect market conditions to change but simply says to himself, in effect, "Declining to sell for a while will yield me a better price in the end, all other things being equal. Therefore, I will not act now." In some circumstances, inaction motivated in this way clearly must be acceptable. Consider three hypotheticals.

The Ordinary Monopolist - Suppose for the moment that there is a physicals market, but no futures market, in stringbeans, and that Long has a monopoly in them, which he has acquired through "superior skill, foresight, and industry." 23 Long maximizes his profits at a price well above his marginal cost. Thus, it would be well worth his while to supply more product if he could do so without lowering his price. Put another way, the decisive reason he withholds supply from the market is the price impact of this restraint. The monopolist who acts in this way does nothing unlawful - so long as he commits no illegal conduct, he is entitled to charge his profit-maximizing price. ${ }^{24}$

21. Perdue, supra note 7 , at 378.

22. See supra text accompanying note 19.

23. United States v. Aluminum Co. of Am., 148 F.2d 416, 430 (2d Cir. 1945).

24. Berkey Photo, Inc. v. Eastman Kodak Co., 603 F.2d 263, 294 (2d Cir. 1979), cert. denied, 444 U.S. 1093 (1980). 
Now let us introduce futures trading into this market, but with only a few contracts outstanding, so that the futures market has no significant economic impact. It makes little sense to hold that this change transforms Long's restraint, which previously was perfectly legal, into manipulation. Thus, the simple fact that conduct was decisively motivated by its anticipated price impact is not sufficient to characterize it as manipulative.

The Early, Thin Market - A distant futures month has just begun trading, very slowly. As of now, Long is the only trader with a long position, and his is substantial and completely speculative. A new trader is eager to buy a substantial long position and has bid a significantly higher price than Long has just paid. Long finds attractive the opportunity to turn a quick profit, and if the choice were between accepting that bid and declining to sell to the new trader at all he would accept the bid. He also has a strong sense that if he does not jump immediately the new trader will raise the bid a tick or two. It seems clear to me that Long legally may play "hard to get," just as he might in any other market, without being guilty of manipulation.

Defensive Self-Restraint - Long has decided to unload a large long position. Having made that decision, he would offer the whole block for sale at once - except for his expectation that to do so would flood the market and bring him poor prices. More likely, therefore, he will sell off little by little. This means that, at any given time, he refrains from selling his remaining contracts because of his expectation of the impact on price that such conduct would have. Clearly such prudent and ordinary market tactics should not be considered manipulation. ${ }^{25}$

Plainly, then, we have to go beyond the price-impact test: it states a necessary but not sufficient condition to characterize conduct as a squeeze. Part II attempts to discern what distinguishes a squeeze from other conduct falling within the price-impact test.

\section{Developing the Modified-SANCtions APPROACH}

Recall the hypothetical episode presented in the introduction to

25. Perhaps we could sort out at least the Defensive Self-Restraint situation by saying that there the inaction - refraining from selling - does not cause a price change, but rather leaves the price where it was; it is the sale from which the trader refrained that would have caused a change. This, however, seems too flimsy a basis on which to make any distinction. Manipulation can consist of artificially stabilizing a price that otherwise would have fallen. In re David G. Henner, 30 Agric. Dec. 1151, 1228 (1971). We have seen that inaction can be manipulative when another course of conduct - such as making an immediate sale - would be chosen but for the fact that the price impact of inaction on price is preferable. This is true when the price impact is positive for inaction and nil for the decision to sell; it seems no less true when the price impact is nil for inaction and negative for the sale. 
this article. In this Part, I present first Long's account, and then the account of an aggressively-litigating claimant. Comparing these accounts will then help us probe the nature of the commodities squeeze.

\section{A. The Defendant's Account}

Long may attempt to show in his defense that his delay in loosening his grip on the market was not at all based on his anticipation of how that delay would affect market price. In particular, he may contend that he needed the physical commodity; thus, he accepted delivery on some of his futures contracts, and sold others only when he was able to satisfy his need in some other way or was offered a price high enough to compensate him for the loss of the physical product.

Now suppose that the factfinder does not find credible this or other contentions denying that the anticipated price impact was a decisive factor guiding Long's conduct. ${ }^{26}$ Long might then argue,

I had the foresight, far in advance, to realize that supplies would likely become tight. So I bought a large long position in the commodity. Supplies did indeed become tight, perhaps in large part because of the failure of the shorts to have similar foresight and get beans to the market, and prices rose. Sure, I could have sold out my position and brought the market tumbling down, but why should I have done so? Just like an ordinary firm with large holdings in an ordinary market, I was more hesitant to sell than I would have been if I had only small holdings. But just like such a firm, I followed the course that would maximize my profits, and made the most of my foresight. ${ }^{27}$

\section{B. The Claimant's Account}

Not surprisingly, the claimant will have a far different account of Long's role in the incident. The claimant might concede that, in a very important sense, Long did nothing worse than any other market actor. Long fairly acquired certain assets - physical product and contractual rights - and then, like any other market actor, determined his profit-maximizing strategy. Any other actor is entitled to sell as much or as little of his physical commodity as he wants, at whatever price the market will bear. Any other actor is entitled to hold on to his futures contracts for as long as he wants, even accepting

26. See supra my discussion of three theories that Long might offer to show that the price impact of his conduct was not a decisive factor behind that conduct.

27. The Administrative Law Judge in Abrams appears to have accepted this argument when he held that the respondent's actions in attempting to liquidate his dominant long position "were taken with the purpose of extracting the best possible price for his long positions, which he established after correctly divining the market's future direction. . . [ [H] did nothing beyond what speculators normally do, and indeed must do to make the market function." In re Abrams, [1987-1990 Transfer Binder] Comm. Fut. L. Rep. $\llbracket 24,408$, at 35,786 (Feb. 8, 1989). 
delivery on them if that will improve his economic situation. Thus, Long appears to have made ordinary market decisions for the ordinary purpose of determining rationally, by taking all factors into account, what his profit-maximizing strategy should be.

In the claimant's view, however, part of the source of those profits, exploited to the full by Long, was the vulnerability of the short traders. To understand this view, we must focus on certain characteristic elements of a traditional ${ }^{28}$ futures contract.

Short selling is central, not peripheral, to a futures market: Recall that there is a short for every transaction. Another of the market's distinctive features is its anonymity. Traders must be able to enter into contracts confidently, without having to rely on the good faith of the trader on the other side. And the clearinghouse, which takes the long position to every short and the short to every long, ${ }^{29}$ must similarly have nearly absolute confidence in the traders. Each trader's obligation to the clearinghouse is created by virtue of her contract with another trader, rather than by direct dealing with the clearinghouse, and if the trader defaults it is the clearinghouse left holding the bag. Severe sanctions for default are a crucial method by which a futures market ensures highly regular fulfillment of its members' obligations. ${ }^{30}$

Thus, in the typical futures market, a large number of shorts are under a legal compulsion to buy, backed by severe sanctions if they do not. Note the power that this gives a dominant trader such as Long. The short interest in effect adds to the demand for the commodity an inelastic element. That is, no matter how high the price rises - so long as it does not rise above the very high cost to the shorts of the sanctions for default - all the shorts will have to buy relief from their obligations. Either they will buy (or forgo a sale of) the physical commodity so that they can deliver on the contract, or they will have to buy an offsetting contract. Those who cannot find deliverable supply, or another long trader eager to liquidate, will have to deal with Long.

If Long exploits this position - simply holding his position until the shorts grow desperate, and then selling just enough contracts to relieve them - he can profit enormously. In the claimant's view, then, it was Long's decision to use this power over the shorts that

28. That is, as opposed to cash-settlement. See supra note 4.

29. See supra text accompanying note 5 .

30. See, e.g., Chicago Board of Trade, Commodity Trading Manual 51 (1982) (defaulting member is suspended until the contract is performed). Other rules are also meant to prevent default. For example, membership on certain exchanges is very expensive, thus providing security for the members' debts. 1 P. JoHNSON \& T. HAZEN, supra note $4, \S 2.44$, at 332-33. Requirements for clearing members are even stricter. Id. at $\S 2.49$. 
accounts for the steep rise in price just before expiration of the contract.

\section{Ordinary Monopoly and Squeeze Power Compared}

The existence of a large body of shorts who are obligated to satisfy Long's contractual rights, or suffer severe sanctions if they do not, gives Long a degree of power far exceeding that of the monopolist of a product for which there is no futures trading. Some potential buyers of such a product may have a strong desire for it, but they usually are not under legal compulsion to buy it. The monopolist simply refuses to deal with those who do not put a high value on the product; ${ }^{31}$ this enables him to charge a high price to the others. Ordinarily those sales that the monopolist does make will be at a price no higher than the value of the article to the buyer, because at a higher price the buyer would simply do without. Even a perfect monopolist must face what Justice Holmes called "the competition of conflicting desires."32 It is not surprising, therefore, that a monopolist who otherwise acts properly is not prohibited from charging as high a price as he can. ${ }^{33}$

The squeezer, by contrast, takes advantage of shorts who may have no use for the physical product but who must pay a high price, by purchasing either the physical commodity or relief in the form of an offsetting contract, to avoid default. Whereas the monopolist makes his profit by selling physical product to those who value the product independently, the squeezer may make most of his profit by selling relief to those under a legal compulsion to buy. In an extreme case, the squeezer, although potentially a low-cost supplier to the market, removes from the market product supplied at high cost by others. ${ }^{34}$

The securities markets further illustrate the difference between a squeezer and an ordinary monopolist. A given security, like a given commodity, is a fungible item traded on an open market. Ordinarily a trader does nothing improper by acquiring a dominant position in a security - even a total monopoly of it - and refusing to sell; that, after all, is what one does in gaining control of a company. Squeeze

31. I do not mean to put aside the situation in which the item has value to the buyer only because she is obligated to deliver it to a third person, or to use it in making another product that she is obligated to deliver to a third person. But the buyer's failure to meet her obligation will usually create liability only for those damages actually suffered by the third person; this measure of the item's economic value to the third person will effectively cap the amount the buyer is willing to pay the monopolist to avoid default.

32. Dr. Miles Medical Co. v. John D. Park \& Sons Co., 220 U.S. 373, 412 (1911) (Holmes, J., dissenting).

33. Berkey Photo, Inc. v. Eastman Kodak Co., 603 F.2d 263, 294 (2d Cir. 1979), cert. denied, 444 U.S. 1093 (1980).

34. See Appendix infra. 
power arises infrequently in securities markets, because the short interest at any given time is usually relatively small ${ }^{35}$ and because shorts are generally not required to deliver on a particular date. ${ }^{36}$ Thus, rarely is a large body of traders under an immediate legal compulsion to buy, and those who are so compelled can almost always satisfy their obligations without having to deal with a particular long. Securities markets are not immune from squeezes, however. In those occasional cases in which there is a significant short interest - that is, where the market more closely resembles a futures market - then the shorts may be forced to deal with a dominant long. Both the occasional occurrence of securities squeezes ${ }^{37}$ and their relative rarity ${ }^{38}$ therefore

35. The term "short" is used in different senses in the commodities and securities contexts. One who sells securities on an exchange usually goes short as the term is used in the commodities context, because most often she undertakes an obligation to deliver the securities in the future; under the rules of the New York Stock Exchange, she may deliver within five business days. But if, as is most often the case, the seller already owns the stock, the transaction is not a short sale in the securities sense. In a genuine short sale of stock, which is carefully regulated, see L. Loss, Fundamentals of Securities Regulation 645-51 (2d ed. 1988), the seller delivers to her buyer stock that she has borrowed from a third party.

In 1987, total volume on the New York Stock Exchange was approximately 48.1 billion shares traded. New YorK STOCK ExCHANGE, FACT BOoK 1988, at 75 (1988). Short sales totaled slightly less than four billion. Id. at 83 . Short sales were $8.7 \%$ of round lot volume in 1986 and $8.3 \%$ in 1987. Id. at 59. Specialists' proportion of all short sales was over $40 \%$ in each of those years: "Specialists, in performing their function of maintaining orderly markets, must frequently sell short to meet an influx of public buy orders." Id. At year end 1987, the total of shares listed was approximately 71.8 billion, $i d$. at 81 , while the short interest was just under 500 million shares, $i d$. at 83. In contrast, short interest in futures by definition represents $50 \%$ of total open interest.

36. A genuine securities short seller, who borrowed the security she has delivered, may hold her position as long as she is able to meet her margin calls - indefinitely, if she has the financial wherewithal to withstand a significant rise in the price of the security. (A securities seller who is short in the broader sense that she has undertaken an obligation to deliver to the exchange does have a very limited time after making her sale in which to deliver, see supra note 35 . For that very reason, at any given time only a relatively small number of traders are obliged to deliver to the exchange, and most of them actually possess the securities.)

A situation more analogous to the commodities markets occurs when a trader sells a "naked" call option; that is, without owning a given security, she sells the right to purchase the security for a particular price on a particular date. J. MiLIER, Options TRAdiNg 100-01 (1975). This practice, however, is relatively limited: most of those who sell call options do so as a hedge against ownership of the underlying security. Id. at 11.

37. See, e.g., Sontag, Stock Manipulation Case a Blast From the Past, NATL. L.J., Feb. 20, 1989, at 13 (describing alleged corner of stock in Chase Medical Group, Inc.); see also A. BRoMBerg \& L. Lowenfels, Securities FraUd \& Commodities Fraud § 4.6 (455) (1975) (corners are possible in securities markets but are more likely to occur in commodities markets because of the expiration date built into futures contracts, the equal number of short and long positions in any contract, the seasonal variations in supplies of many commodities, and the logistics of delivery). Also, although failure to deliver securities gives rise to liability for damages, suspension is not inevitable. See Rules of Board: Settlement of Contracts, 2 NYSE Guide Dealings and Settlements (CCH) I 2180 (Feb. 9, 1968). Depending on how damages are calculated, the value to a short of avoiding default may be less than in the commodities markets.

38. See Sontag, supra note 37 ("[M]ost of the SEC staffers working on [the Chase Medical Group case] had never tackled anything like it, the American Stock Exchange went back to the 
illustrate the importance of a large short interest, subject to severe sanctions, in making commodity squeezes attainable.

\section{Defining a Squeeze and Developing a Test}

We have seen that, although ordinary monopoly pricing and a squeeze both involve withholding supply from the market to push the price up, only the squeezer does so by exploiting the vulnerability of the shorts to sanctions. This distinction suggests a concise definition of a squeeze, modified from the price-impact test: To qualify as a squeeze, the price impact of the trader's conduct in exploiting the vulnerability of the shorts to sanctions for default must be a but-for cause of the conduct. The preceding discussion supports the theoretical accuracy of this definition, but transforming it into an operational test requires further analysis.

1950s before it could recall a similar matter, and one standard business-school textbook describes the fraud as so improbable it is "of historic interest only.' ").

In addition to the factors discussed in the text, another consideration might help explain the relative rarity of the securities squeeze: a bright line rule for determining whether a squeeze has occurred is more workable for securities than for futures. That makes securities squeezes more easily detectable, and also gives traders clearer warning of the conduct they should avoid. The bright-line rule, simply stated, is this: A trader may not buy rights to more than the amount of the security outstanding. Cf. 3 L. Loss, SECURITIES REgulation 1538 n.26 (2d ed. 1961) ("A corner is a purchase of more than the available supply of a security (or commodity) with the intention of forcing settlement from short sellers at the purchaser's figure.").

One reason the rule works reasonably well in the securities context is that it is easy to determine when the rule is violated. Moreover, the rule usually yields sound results. If a securities trader violates the rule, he is probably squeezing, because no valid reason for such an acquisition is apparent. And if the securities trader does not violate the bright line rule, it usually is difficult to conclude that he is squeezing, because he can say that his intention was simply to acquire and retain more of the security than he previously had (and, in the case of common stock, a controlling interest in the company). The plausibility of this alternative explanation would make it almost impossible to prove that such a trader's conduct actually was determined by its price impact and his willingness to exploit the shorts.

Now consider the difficulties that would beset a comparable rule in the futures context. Instead of speaking of outstanding securities, such a rule would be worded in terms of deliverable supply. But often there is a good deal of ambiguity as to what supply is deliverable or can be made deliverable before the contract expires. See infra text accompanying notes 47-48. Moreover, a futures trader who buys contracts for more of a commodity than is currently deliverable may have innocent explanations; he may, for example, not have any firm idea of just how much is deliverable, or he may legitimately need more than is currently deliverable. And, on the other side of the coin, even if we could say confidently that the trader did not buy contracts for more of the commodity than is or would be deliverable, we cannot say confidently that he is not squeezing. A trader might, for example, buy a large position while supplies are still plentiful, and then gain squeezing power simply by holding on to the position while attrition diminishes the amount of deliverable supply. Or, even if the trader's position is always less than the amount of supply technically deliverable, the trader may still have some squeezing power if a significant amount of that supply is committed elsewhere and could not be made available for delivery against futures obligations without incurring substantial additional costs. See generally Perdue, supra note 7, at 383-85 (criticizing the definition of manipulation suggested in McDermott, Defining Manipulation in Commodity Futures Trading: The Futures "Squeeze," 74 Nw. U. L. REv. 202 (1979) "threatening to take delivery of the same thing twice" - for failing to explain why it is improper for the long to expect the shorts to fulfill their contractual obligations). 
The proposed definition requires the factfinder to ask whether the defendant withdrew or withheld from the market the same amount of supply that he would have had he not taken into account the price impact of the shorts' vulnerability to default. Thus, the standard against which the defendant's conduct is measured is one of self-abnegation - he is required to put out of mind an aspect of reality that might in fact have been beneficial to him. In effect, the factfinder needs to devise a hypothetical market that lacks the shorts' vulnerability but otherwise is as close as possible in material respects to the actual market, and then ask whether Long would have withheld supply from that market to the same degree as he actually did.

The vulnerability exists because (1) there is a large body of shorts, and (2) they are subject to severe penalties for default. We could thus create an imaginary market without vulnerable shorts by hypothetically altering either of these conditions.

This choice raises an interesting ambiguity, somewhat akin to one noted with reference to the price-impact test. ${ }^{39}$ The analysis proposed here asks how a trader would have acted but for a given condition, the vulnerability of the shorts. It is apparent, though, that this condition could, hypothetically, be removed in more than one way. And how the trader might act would presumably depend on just how the condition is removed - that is, on just what hypothetical we imagine.

This ambiguity, I suspect, infects virtually all causation tests based on counterfactual hypotheses. ${ }^{40}$ I do not believe I need linger over the difficulty here. Ordinarily, at least, it is too large an alteration of material reality to imagine that the short futures interest was very small. ${ }^{41}$ It is better instead to imagine an alteration of the rules determining sanctions, for they are imposed on the market rather than reflecting the forces of supply and demand. Thus, we can ask how Long would have acted if the system of sanctions did not augment his power over the shorts.

In actuality, the penalties for default are so heavy that a short will

39. See supra note 17.

40. See Cole, Windfall and Probability: A Study of "Cause" in Negligence Law (pt. 2), 52 Calif. L. Rev. 764, 776-77 (1964).

41. If the short open interest were very small, then Long could not have his corresponding long futures position. This means at the very least that the hypothetical alteration of the market is not a simple one; we are imagining not just a change in the environment but in Long's own holdings. Perhaps it would be useful in some cases to ask a question such as: "Long stood for delivery of physical commodity of a given amount when price was at a certain level. If Long did not have futures for that amount, would he have bought that quantity in physicals at that price?" But in other cases Long could justly contend that his futures position was his means of gathering up supply early, and that he should be allowed to reap the rewards of doing so, just as a trader in a market without futures contracts would be. 
almost always pay the market price rather than default. Moreover, if damages are measured by market price, Long's power over the shorts would not be significantly diminished even if the other penalties for default were mild. Long's ability to withhold a substantial amount of supply from the market gives him the ability to select the market price that maximizes his profit, including the profit from damages payments by the shorts. Given that those damages themselves are measured by market price, Long has a strong incentive to withhold supply and drive the price higher. Higher prices will encourage more shorts to deliver, giving Long product that he does not want and of which he must dispose. Yet no matter how high the price goes, those shorts who cannot deliver would still find it better to liquidate at the market price than to breach and to pay penalties in addition to market price damages.

Now suppose that the only sanction on a defaulting short was that prescribed by the general rule of Uniform Commercial Code (UCC) section 1-106 - that is, payment of the amount of damages that would "put [the long] in as good a position as if the other party had fully performed." 42 What would the long's conduct be if this were the prevailing rule? We can break this question down into three parts.

First, if this were the rule, how would breach by a short alter the long's situation? In other words, what would the damages be? The answer to this question ultimately depends on Long's need for the product. Consider two cases. In Case 1, Long has use for additional product at the market price, even after he has produced all he can supply himself at marginal cost below that price, and even though he believes he could buy product at substantially lower prices at a far distant point or at a later time. Thus, the breach means he must either do without the product here and now or cover at the market price. In this case, damages presumably would be the market price less the contract price.

Alternatively, as Case 2, suppose that Long has no need for additional product at this time and place; indeed, he is already pressing the price up by withholding supply from the market (as either a squeezer or an ordinary monopolist might do). In that case, additional product delivered by the short would simply have been added to Long's holdings and sold later (if at all), presumably at a lower price. ${ }^{43}$ Damages

42. U.C.C. $\$ 1-106$ (1989).

43. Perhaps Long would argue that, if the short had delivered, that would have taken available supply from other shorts, and made them eager to liquidate at a higher price. Such an argument is circular; it essentially treats Long's ability to squeeze the market as an asset entitled to legal protection. Moreover, this argument assumes that the short's performance would have been by delivery of product that otherwise would have been delivered by another short. 
- if any - should be no greater than the excess of that later price, rather than the current market price, over the contract price. Moreover, if Long could cover for the undelivered beans by producing additional beans himself more cheaply than that lower price, then damages should probably be equal to the cost of production less the contract price. This analysis appears to be in accord with general principles of contract damages. ${ }^{44}$

Second, given the appropriate measure of damages, what would the shorts do? As we have seen, where the measure of damages is the market price less the contract price, as in Case 1, a short presumably would comply with her contracts: breach would offer her no advantage compared to default, and would involve some penalties. Even if she did breach, the long's position would not be materially altered, because the damages award is designed to allow him to buy what he needs on the market.

In Case 2, however, where the measure of damages is based on the anticipated drop in the market, or on a cost of production lower than the market price, then presumably the shorts would breach. In these cases, it would be cheaper to breach than to deliver. What is more, in such a case breach would be the most efficient course of conduct: 45

44. Although market-price damages are most often available for the buyer who chooses not to cover, see U.C.C. $\$ 2-713$ comment 5 (1989), they are not always appropriate. As Justice Stone wrote long ago, "The test of market value is at best but a convenient means of getting at the loss suffered. It may be discarded and other more accurate means resorted to if, for special reasons, it is not exact or otherwise not applicable." Illinois Cent. R.R. v. Crail, 281 U.S. 57, 6465 (1930). As my colleague James J. White has pointed out, courts have adhered to this flexible approach even in the face of the seemingly absolute language of UCC $\$ 2-713$. White, The Decline of the Contract Market Damage Model, 11 U. ARK. LITTLE Rock L.J. 1, 2 (1988). In Nobs Chem., U.S.A., Inc. v. Koppers Co., 616 F.2d 212 (5th Cir. 1980), for example, the court considered $\S 2-708(2)$, which supplements the market-price rule when it is "inadequate" to put the seller in as good a position as she would have been under performance. This rule cuts both ways, the court held: If the market-price rule provides excessive damages, it should be abandoned. 616 F.2d at 215. For the reasons stated in the text, Long's Case 2 is one of those in which the market-price rule overstates damages. $C f$. Dura-Wood Treating Co. v. Century Forest Indus., 675 F.2d 745 (5th Cir.) (recognizing internal cover as a valid remedy), cert. denied, 459 U.S. 865 (1982); J. WhITE \& R. Summers, UNiform CoMmercial CODE $\S 6-4$, at 253 (3d ed. 1988) (drafters of the UCC probably did not intend to supplant the remedy available under $\S 2-712$ by allowing a higher award under $\S 2-713$, thus giving buyers an incentive not to cover).

Courts sometimes go beyond treating market-price damages as excessive; under the doctrine of hindrance, which may amount to a rough form of antimanipulation law, a defaulting seller can avoid damages by showing that the buyer's actions completely prevented performance. See $5 \mathrm{~W}$. JAEGER, WILLISTON ON CONTRACTS § 677A (3d ed. 1961); RestaTEMENT OF CONTRACTS $\S 295$ (1932) (illustration 3). Indeed, in earlier times, activity that interfered with the supply of goods to the market constituted the criminal offense of forestalling. G. CRABB, A HISTORY OF ENGLISH LAW 312 (Burlington ed. 1831).

45. See, e.g., R. POSNER, ECONOMIC ANALYSIS OF LAW 107 (3d ed. 1986) (promisor has incentive to breach where profit from breach, less damages equal to promisee's expected profit from completion of contract, exceeds expected profit from completion of the contract). But see Friedmann, The Efficient Breach Fallacy, 18 J. LEGAL STUD. 1 (1989) (criticizing efficient breach theory because, inter alia, courts may improperly assess expectation damages; also, a unilateral 
delivery would mean that additional supply is brought to the market at high cost, only to be held by Long until a later time when Long resells to low-value users.

Third, given the anticipated action of the shorts, what would the long do? In Case 1 - that is, where Long needed the physical product - he would effectively use his futures contracts to make desired purchases. Either the shorts would deliver or he would use a sum awardable in damages to cover on the market. Clearly, he would not have any incentive to push the price any higher than he would if the contracts were ordinary cash contracts for the commodity. The shorts would not be vulnerable to default.

Nor - and this is the key - would the shorts be vulnerable in Case 2, in which Long's holdings are more than he needs, given the market price. Given that the market price is higher than the cost of breach, pressing the market price higher would not exploit the shorts - they would all breach anyway and pay damages. Long's best alternative therefore would be to mitigate his damages, setting the price and output that would maximize his profit from sale of physicals and then collecting damages from the defaulting shorts. That output may be restrictive - it may, that is, reflect the market power that Long's extensive holdings give him - but it is not based on vulnerability of the shorts to default sanctions.

This, at last, appears to solve the problem. If ordinary contract damages, as measured by UCC section 1-106, were the only sanction against a breaching short, then the shorts would not have had any vulnerability to default that Long could have exploited. The way Long would have acted had this been the rule therefore presents the standard against which his actual conduct should be measured.

We can now create an operational test of a squeeze. Recall that the price-impact test created a necessary but not sufficient test for a squeeze. The analysis presented here shows that the long trader's conduct should be considered a squeeze only when the anticipated price impact underlying that conduct results from the vulnerability of the shorts to sanctions for default. We could therefore ask, "Would the long trader have engaged in the same course of conduct if the price impact of that conduct were the same as in a market in which the only sanction for default were the ordinary measure of contract damages?"

The test is, however, considerably more tractable if broken down into two parts. First is the price-impact test: Is there any less restric-

breach potentially leads to a costly dispute over damages, thus exhausting any savings in transaction costs). 
tive course of conduct that the trader would have found preferable to his actual conduct if the actual conduct had in fact led to the same price as this less restrictive course? This is a "safe harbor" test, because if the answer is negative the conduct should, without further inquiry, be considered not to be a squeeze. If the answer is affirmative, it then becomes necessary to ask a second question: If the only sanction for a short's default were the ordinary measure of contract damages, would the long trader have withheld supply to a lesser extent than he did? If the answer to this question, as well as the first, is affirmative, then the trader squeezed the market. ${ }^{46}$ I shall call this two-part approach the modified-sanctions test.

Lest there be any confusion: I do not suggest that the sanctions for default actually should be limited to damages under section 1-106. I take it as essential for the proper function of the futures market that the shorts ordinarily regard default as virtually unthinkable. But the sanctions for default are meant to ensure performance by the shorts. They are not meant to distort the conduct of a dominant long, encouraging him to take an economically inefficient course so that performance by the shorts will be hindered and he can exploit their desperation. Thus, it makes sense to require the long to act as he would if the sanctions merely compensated him for any loss caused by a breach.

\section{Evaluating the Modified-Sanctions Test}

This Part evaluates the modified-sanctions test by examining how it relates to four criteria that are essential elements of a squeeze under what may be called the "classical" definition: ${ }^{47}$ market dominance,

46. Logically, this two-part test is not completely equivalent to the question in quotation marks: A case could be conceived, perhaps, in which the price impact of a trader's conduct and the sanctions rule were both but-for causes of that conduct, but the price impact of the conduct attributable to the sanctions rule was not. Such a case would be rare at best. Even if the result of the unitary test in this case were better, which is by no means clear, the two-part test would be generally superior, because it is easier to articulate, to understand, and to apply. Indeed, the price-impact portion of the test will often screen out clear cases of nonmanipulation.

In most cases, if the defendant loses on the second branch of the two-part test, he would also lose on the first, the price impact issue. Nevertheless, the price impact issue should be retained as part of the test. For one thing, as noted above, it may often act as a screen, obviating the need for fruitless inquiry. Also, in some cases a long might fail on the second branch of the test but not the first, and in these he probably should not be considered a manipulator. That is, it is probably unfair to condemn a long who believes that (1) the price impact of his own position is too small to be a decisive factor in making his trading decisions, but (2) his long position is worth retaining because the shorts will be desperate to avoid default.

47. Various cases and commentaries give different formulations of the classical approach. The one I use here is essentially that of In re Cox, [1986-87 Transfer binder] Comm. Fut. L. Rep. (CCH) I 23,786, at 34,061 (CFTC 1987); see also 3 P. JOHNSON \& T. HAZEN, supra note 4, at 42-44; In re Indiana Farm Bureau Coop. Assn., [1982-1984 Transfer Binder] Comm. Fut. L. Rep. (CCH) \I 21,796, at 27,297 (CFTC 1982) (Stone, Commr., concurring). 
artificial price, causation, and intent.

This discussion has two aims. The first is to show that the modified-sanctions approach yields sensible results, responding to the factors that courts have recognized as relevant, but articulating and explaining their significance better than the classical approach does. The classical approach demands yes-or-no answers to questions that are inherently matters of degree, and so invites linguistic manipulation that makes the questions meaningless. The modified-sanctions analysis avoids this brittleness. Further, it does so without descending into the mush at the other extreme - a wide-open balancing test that would simply tell the factfinder, in deciding whether manipulation occurred, to take into account "all the circumstances." The modifiedsanctions approach does not ignore any relevant circumstance, but it sets forth clearly the bottom-line questions that the factfinder should be attempting to answer as it considers the evidence.

Second, by showing how the standard criteria play a part in answering the question posed by the modified-sanctions approach, I hope to demonstrate that a court or agency could implement this analysis with very little maneuvering even if it felt bound to pay deference to the classical definition.

Market dominance - Under the classical approach, one of the elements of the cornering offense is domination of the combined futures and physical markets. ${ }^{48}$ The classical approach treats the dominance question as binary - that is, as one that can be answered either yes or no. ${ }^{49}$ In seeking an answer to that question, factfinders must answer a closely related question that is also treated as binary: whether a given source of the commodity in question should be considered part of the "deliverable supply," which could have been used to satisfy the shorts'

48. A. BROMBERG \& L. LOWENFELS, supra note $37, \S 4.6(456)$ (no corner can be effective unless the trader has a sizable long position at the critical time and, if the cash supply is large enough to be a significant factor for the shorts, the trader must also control the cash supply to some degree). As indicated before, see supra note 3, I draw no sharp distinction between a squeeze and a corner; although a corner is sometimes said to require dominance of the physical supply, a squeeze presupposes enough control over the futures contract to acquire a dominant position in the market for physicals.

49. Compare Great Western Food Distrib. v. Brannan, 201 F.2d 476, 481 (7th Cir.) ("a coincidence of Great Western's dominant long position and control of the available cash supply"), cert. denied, 345 U.S. 997 (1953) and In re Compania Salvadorena De Cafe, [1982-1984 Transfer Binder] Comm. Fut. L. Rep. (CCH) \21,886, at 21,817 (CFTC 1983) (artificial price "was caused by Falla's acquisition and maintenance of a dominant long position in the future for Salvadorena's accounts") with Volkart Bros., Inc. v. Freeman, 311 F.2d 52, 59 (5th Cir. 1962) ("In the present case, the petitioners did not control the supply of "certificated cotton." ") and In re Cox, [1986-1987 Transfer Binder] Comm. Fut. L. Rep. (CCH) 1] 23,786, at 34,063 (CFTC 1987) ("Cox and Frey could not foreclose the shorts' delivery option and thus lacked the ability to influence market prices."). See also In re Indiana Farm Bureau Coop. Assn., [1982-1984 Transfer Binder] Comm. Fut. L. Rep. (CCH) $₫ 21,796$, at 27,302 (CFTC 1982) (Stone, Commr., concurring) (objecting to the binary treatment of the deliverable supply issue). 


\section{futures obligations. ${ }^{50}$}

This binary treatment is a serious flaw in the classical approach, because dominance is inherently a matter of degree. As the Appendix shows, the extent of a long trader's dominance varies, depending on how much additional product other market actors would be able to supply at high prices; on how much product buyers would demand at high prices; and on how large a long position the purportedly dominant trader had.

The Appendix assumes away the question of deliverability, ${ }^{51}$ but that too is usually a matter of degree, or more precisely a matter of price - inconvenient supply can often be feasibly delivered if the price rises far enough. ${ }^{52}$ The more feasible delivery of a given supply is, the less dominance a large trader has.

Now examine the significance of market dominance under the

50. See, e.g., Cargill, Inc. v. Hardin, 452 F.2d 1154, 1165 (8th Cir. 1971) (hard wheat excluded from the deliverable supply of wheat), cert. denied, 406 U.S. 932 (1972); Great W. Food Distrib., 201 F.2d at 480-81 (fresh eggs and out-of-town refrigerator eggs excluded from the deliverable supply of eggs), cert. denied, 345 U.S. 997 (1953); Volkart Bros., Inc. v. Freeman, 311 F.2d 52, 59 (5th Cir. 1962) (uncertificated cotton included in the deliverable supply of cotton); In $r e$ Indiana Farm Bureau Coop. Assn., [1982-1984 Transfer Binder] Comm. Fut. L. Rep. (CCH) If 21,796, at 27,287 (CFTC 1982) (corn "not irrevocably committed" included in the deliverable supply of corn); In re Cox, [1986-87 Transfer Binder] Comm. Fut. L. Rep. (CCH) I 23,786 at 34,061-63 (CFTC 1987) (committed wheat in Chicago excluded, but barge wheat controlled by the dominant short and premium grades of wheat in Kansas City included in the deliverable supply of Chicago wheat).

51. See infra Appendix.

52. Consider, for example, the heroic efforts made by Philip Armour, who found himself caught short without deliverable stocks of wheat in 1897. T. HIERONYMUS, supra note 4, at 323. Stocks in Chicago declined from 10 million bushels in late April to 1.7 million bushels in late August, amidst rumors of a corner and of small European and Indian crops. Armour's valiant efforts to move wheat into deliverable position included "running tugs continuously and using dynamite to keep the frozen waterways open from Duluth." Id. By the end of December, stocks of wheat rose to 9.7 million bushels, and Armour filled all of his contracts. Id. Armour's experience shows that, sometimes at least, enough money can buy almost anything. $C f$. $O$. HeNRY, Mammon and the Archer, in THE COMPLETE WORKS 53 (1953) (money used to buy time, and time used well to acquire love).

Determining what supply is deliverable is closely akin to determining the bounds of the "relevant market" in an antitrust case, an enterprise on whose value some noted scholars have sagely cast doubt. For example, Philip Areeda and Louis Kaplow argue:

It cannot be emphasized too strongly that market definition and the defendant's market share give, at best, only a suggestion of defendant's market power. The boundaries of any product and geographic market are necessarily imprecise. The universe of existing producers, however broadly defined, cannot account for ease of entry by other firms. Nor do market shares speak of relative production costs, the expansion potential of other firms, their independence or dynamism, scope and direction of market changes, buyer power, or nonmarket forces. In addition, market power is intrinsically a matter of degree, which is often lost sight of by a process of market definition that either wholly includes or excludes substitutes at the initial stages of the assessment. But even if such problems are overcome, the power implications of any particular market share remain obscure.

P. AREeda \& L. KaPLOW, ANTITRUST ANALYSIS 580-81 (4th ed. 1988). Frederick Rowe goes even further:

In my view, the concept of "the market" is the weakest link in antimonopolization and antimerger law. Having eluded antitrust scholars for over a generation, the "correct" mar- 
modified-sanctions approach. Unless a trader has a dominant long position, his purchases (or refusals to sell) cannot move the market in a way that will profit him. If a trader with only a small long position refuses to liquidate, he will probably have no significant market impact at all. A trader with a more substantial, but not dominant, long position may cause a price increase if he delays liquidation, but he will probably not be able to profit from it. Most of the shorts will probably be able to go elsewhere to cover their obligations, and when the long finally does liquidate he may well bring the market down by as much as he previously raised it. When a long trader substantially dominates the market, however, so that a large number of the shorts have nowhere else to go to avoid default, the situation is much different. Then, and only then, can the rational but greedy long trader hope that an otherwise unwarranted refusal to liquidate will be a sensible strategy, because the refusal itself likely will drive the price far higher.

In the modified-sanctions model, then, the issue of market dominance plays its proper role. Unless the trader had a dominant position, it would not have made sense for him to make buying and selling decisions with the hope that he could profit from the impact of his conduct on market price. The more dominant the position, the more attractive a squeeze is to the greedy trader - and thus the more likely it is an accurate explanation of his behavior. Thus, under the modified-sanctions model, a factfinder would not answer the dominance question yes or no, but would attempt to gauge the extent of market dominance. In doing so, the factfinder would not be required to ask artificial binary questions such as, "Should those distant beans be considered part of the deliverable supply?" Instead, it would ask questions of economic substance, such as, "Given the difficulty in getting those beans to market, how much power did the defendant have to push the price up simply by delaying liquidation?"

Price Artificiality - Under the classical model, analyses of manipulation have often turned on whether the price of the futures contract in question was artificial. Sometimes this inquiry has depended on whether that price was historically unusual, either absolutely or in re-

ket remains a mirage. On the eve of antitrust's centennial celebration, waiting for the mar-

ket is waiting for Godot.

By now, wise observers know that competition defines the market, not vice versa; that no market can contain competition among modern multi-product firms; that the market is a still snapshot in frozen time, unable to sense change or innovation; that the process of competition defies quantification; and hence that the concept of a finite, objectively defined market is an ever-receding mirage.

Rowe, Market as Mirage, 75 CALIF. L. REv. 991, 991, 995 (1987) (emphases in original; citations deleted). 
lationship to other prices. No doubt, as Perdue acknowledges, an unusual price is relevant evidence in determining the probability that a market was manipulated. ${ }^{53}$ But, as she correctly argues, an unusual price is not conclusive evidence of manipulation. ${ }^{54}$ It may merely reflect an appropriate market response to unusual conditions.

An alternative approach is to define an artificial price as one not reflecting the legitimate forces of supply and demand. ${ }^{55}$ This approach obviously and overwhelmingly begs the question. A trader's decision to buy or to retain a long futures position certainly cannot be considered illegitimate simply because he has no desire for the physical commodity represented by the contract; the vast majority of ordinary futures purchases, both speculations and hedges, are made by traders who have no expectation of taking delivery. Nor would it suffice to say that the futures price is artificial if it does not reflect the "real world" factors of supply and demand in the physicals market. That presupposes the illusory ability to determine with confidence just what, and how strong, those factors are and which price they would yield if not tainted by some improper factor. Moreover, trading decisions in the futures markets ordinarily are responses to anticipated outside factors. The physicals market may be too thin, and so at any given time may not accurately reflect the factors that traders believe should affect a commodity's price. Often it is the futures market, with its greater liquidity and ease of trading, that better registers these factors. If the futures market leads the physicals market, it is probably just performing its job.

The modified-sanctions analysis offers a satisfactory solution to these difficulties. Recall the element of artificiality in Long's case: his ability to drive the price up sharply was not based principally on the value of the uses to which potential buyers would put the physical commodity. Rather, the key factor was that the shorts needed to avoid default, and with it the draconian sanctions that far exceeded any value of the physical commodity. In an actual case, it may be impossible to assess whether, or to what extent, that factor has actually determined the price. Fortunately, we do not necessarily have to do so; it is enough if the long's expectation of such a price impact was a but-for cause of his conduct.

Such a determination does not depend on characterizing the resulting price as artificial. But neither is the analysis stymied if binding law

53. Perdue, supra note 7 , at $369-70$.

54. Id.

55. Id. at 370 ; T. Russo, supra note $3, \S 12.24$. 
is deemed to make the price artificiality question critical. Given that the sanctions for default far exceed the economic loss caused by breach, it is easy to characterize as artificial any price resulting from a long's attempt to exploit the shorts' vulnerability to those sanctions.

Suppose, for example, that Long gives the following soul-baring explanation of his decision to retain his large long futures position until just before expiration:

I had no use for the physical beans represented by these contracts. And the price of these contracts was very high in relation to historical levels, to physical string beans available elsewhere, to futures contracts in other months, and to other commodities that usually have similar trading patterns. Therefore, it wouldn't have made sense for me to hold my position as long as I did, except that I knew that the longer I held it the more desperate the shorts would become, because they had to deal with me or default and face very expensive sanctions. Thus, holding out to the last minute drove the price way up, and I profited handsomely.

Surely it does no violence to language to label as illegitimate the demand represented by Long's decision to delay liquidation, or to say that the resulting price is artificial. Of course, most defendants will not readily admit improper motivation. A factfinder might nevertheless be able to infer the defendant's true motivations from the circumstances.

In making that inference, the factfinder might rely in part on a historically unusual pricing pattern. Just as in the classical approach, the factfinder might determine whether the price of the future in question was abnormally high, either absolutely or in comparison to other prices - for physicals, other contract months, or other commodities. If it was, that may be relevant for at least two reasons.

First, the greater the price abnormality, the greater the likelihood that something unusual caused it. Perhaps that something was a rare congruence of fundamental factors, or perhaps it was a negligent failure of the shorts to enable themselves to make delivery. But it could also have been the conduct of the defendant, in refusing to let go of a large long position as the contract neared expiration.

Second, as suggested by Long's confession, a price abnormality should make the factfinder ask seriously why the defendant acted as he did in holding on to his position. There may well be innocent explanations - if, for example, the defendant had real need of the physicals that he could gain by standing for delivery. The more the price of the expiring future was out of kilter, however, the more likely that the defendant's decision was motivated by his realization that his steadfastness could drive the price upwards. If the defendant was not manipulating, then a large abnormality would usually be corrected 
rather quickly by market forces - or at least the defendant would expect such a correction, and so would be unlikely to hold his position rather than cashing in quickly at an apparently attractive price.

Causation - The classical approach asks whether the long trader's activity caused the elevated price. ${ }^{56}$ If the question is taken literally, the answer is obvious: Of course the conduct of a large long trader, in buying contracts or declining to sell, is a significant factor in determining the price, in the sense that the price would be lower if the long did not hold such a large position. Alternatively, the question of causation may be taken to state a more difficult issue: Who should be blamed for the sharp price move - the shorts, who failed to move enough supply into deliverable position, or the long, who insisted on holding the shorts to their obligations? ${ }^{27}$

Once more, the modified-sanctions approach provides a satisfactory solution to the conundrum. If the long would not have held his position but for the anticipated impact that it would have on market price by increasing the pressure on the shorts to avoid default, then he is guilty of manipulation, even if the shorts had no good excuse for their inability to perform. The reason is plain enough. If that anticipated price impact was critical to the long's decision, then he did not hold his position because of its economic value but rather because he could make a profit by putting pressure on the shorts. No economic value lies in allowing the long to profit from such game-playing. Indeed, such a technique, apart from being oppressive to the shorts, creates potentially serious inefficiencies by distorting the price and by encouraging shorts to move supply into deliverable position for no good economic reason. If the long, complaining of unfairness, argues that he has a right to stand on his contract rights, there is a ready

56. "The question is . . . whether the artificially high price was caused by [the long trader,] Cargill." Cargill Inc. v. Hardin, 452 F.2d 1154, 1169 (8th Cir. 1971), cert. denied, 406 U.S. 932 (1972); see also Great Western Food Distrib., Inc. v. Brannan, 201 F.2d 476, 482-83 (7th Cir.) (defendant's conduct must have "resulted in" artificial prices), cert. denied, 345 U.S. 997 (1953); Volkart Brothers, Inc. v. Freeman, 311 F.2d 52, 58-60 (5th Cir. 1972) (conduct must "produce" or "create" artificial prices); In re Cox [1986-1987 Transfer Binder] Comm. Fut. L. Rep. (CCH) II 23,786, at 34,067 (CFTC 1987); In re Indiana Farm Bureau Coop. Assn., [1982-1984 Transfer Binder] Comm. Fut. L. Rep. (CCH) I 21,796, at 27,301 (CFTC 1982) (Stone, Commr., concurring).

57. For a discussion of this issue in terms of causation, see for example, 3 P. JoHnson \& T. HAZEN, supra note 4, $§ 5.21$, at 79-83, which discusses Volkart Brothers, $311 \mathrm{~F} .2 \mathrm{~d}$ 52, and In re Indiana Farm Bureau Coop. Assn., [1982-1984 Transfer Binder] Comm. Fut. L. Rep. (CCH) I 21,796 (CFTC 1982). In each of those cases, the blame was placed on the shorts; by contrast, Cargill, 452 F.2d 1154, put blame on the long.

Notwithstanding harsh treatment by the Cargill court, in recent years Volkart has been accorded substantial respect. See In re Cox, [1986-1987 Transfer Binder] Comm. Fut. L. Rep. (CCH) If 23,786, at 34,062 (CFTC 1987); In re Indiana Farm Bureau Coop. Assn., [1982-1984 Transfer Binder] Comm. Fut. L. Rep. (CCH) ๆ 21,796, at 27,290, 27,292 (CFTC 1982) (Johnson, Chmn., concurring); McDermott, supra note 38, at 220 n.89. 
answer: "Not for that reason you don't. This limitation is read into your contract as a matter of law, so there is no unfairness."

Now suppose by contrast that the long actually did want to hold his position, even without considering the impact on the shorts of doing so. Then it is perfectly appropriate to hold the shorts accountable for their failure to deliver, even if the result of their attempts to cover themselves drives the price sharply up. In other words, a short who holds her position until near the end of the contract month without being in a position to deliver takes a chance. If the contract liquidates in an orderly fashion, so that she has no difficulty finding cover, then she will not suffer. And if there is a price jump but the only reason for it is that a long has decided to take advantage of her inability to deliver, then she will not be held accountable. But if she has misjudged the situation - if a long, without taking into account the difficulty he is creating for the shorts, wants to hold his position until just before the contract expires, or even to take delivery on it, and she is unable to make delivery - then she must bear the consequences.

Intent - Although intent is an essential element of a squeeze under the classical approach, it is the intent to create an artificial price, and this does not advance the analysis. There can be no satisfactory determination of this intent until the problem of defining price artificiality is solved - something the classical approach has not been, and will not be, able to do.

In the modified-sanctions model, by contrast, intent is the central issue; price artificiality is defined, if a definition is deemed necessary, in terms of the intent with which the dominant long undertook the action that caused the price abnormality. Intent in this model is not so much a matter of purpose - the long's aim, whether manipulative or not, is presumably to make money - as of rationale. If the long would have withheld less supply but for his anticipation that his conduct would raise the price by pressuring the shorts to avoid the sanctions for default, then he has acted manipulatively.

I have suggested that this "but for" test be broken down into two parts. The first asks how the trader would have acted but for his anticipation of the price impact of his conduct; the second asks how he would have acted under a lesser system of sanctions. Both questions depend on hypotheticals, and that might seem to present problems. Given that the trader held a large position, his conduct, whether active or passive, almost certainly did have a significant price impact. It therefore does not seem useful in presenting the first question to suppose that the conduct did not have any actual or anticipated impact on prices; that would require that in our hypothetical world fundamental 
economic law be suspended, or at least that the trader thought it was. We should, therefore, ask what the long would have done if he simply did not take the anticipated impact into account. The second question, similarly, asks what the long would have done had he put out of mind the additional pressure created by a system of punitive sanctions for default.

It might seem strange to base the determination as to whether trading is manipulative on what the trader hypothetically would have done had he ignored perhaps the most significant impact of his decision or a key rule of the market in which he operated. But remember that a squeeze may be rational economic behavior given the circumstances, an attempt by the long to maximize profits by taking into account all relevant considerations. The essence of the ban on squeezing is not that the aim of the long - maximizing profits - is improper. Rather, it is that in doing so there are some factors that a dominant long must not attempt to exploit; in other words, he must put certain profit considerations out of mind. There is nothing remarkable about a rule requiring a person to act as he would if some aspect of reality were altered or disregarded. ${ }^{58}$

I do not pretend that it will always be easy to determine whether an alleged squeezer has acted in this way. A trader will rarely articulate a manipulative rationale, perhaps not even to himself. As in many other legal contexts, the factfinder must operate from circumstantial evidence. There will usually be many clues: Did the long refuse to sell even though his contracts were priced abnormally high, in absolute terms or in relation to other contracts? Did he unload at a substantially lower price much of the commodity on which he had stood for delivery? Or, on the other hand, did he put the physical commodity to a use for which there was no cheaper alternative? There is nothing novel about asking these evidentiary questions in a squeeze case. The approach presented here, however, shows their true significance - as aids in answering the bottom-line question of whether the defendant

58. For example, a fiduciary must disregard the consequences for his own welfare of conduct that also effects the beneficiary of his trust. E.g., Meinhard v. Salmon, 249 N.Y. 458, 164 N.E. 545,548 (1928) (by becoming a fiduciary, defendant "put himself in a position in which thought of self was to be renounced, however hard the abnegation") (Cardozo, C.J.); IIA A. ScoTT \& W. Fratcher, THE LAW OF TrusTs 436 (1987) ("his interest must yield to that of the beneficiaries"). And, although it would "ignore reality" to deny the risk of possible injury that private biases might inflict on a child living with a step-parent of a different race, a judge may have to do just that; such biases and risk are not "permissible considerations for removal of an infant child from the custody of its natural mother." Palmore v. Sidoti, 466 U.S. 430, 433 (1984). Indeed, as Fred Schauer points out, inherent in the nature of any rule is that it screens off one or more factors that the decisionmaker would otherwise take into account. Schauer, Rules, the Rule of Law, and the Constitution, 6 CONST. COMM. 69, 83 (1989); Schauer, Formalism, 97 YALE L.J. 509, 544 (1988). 
would have acted the same way but for the anticipated pressure that his conduct would impose on shorts vulnerable to default.

At the end of the day, the factual issue may still be in substantial doubt. This does not condemn the modified-sanctions approach, however. Uncertainty in the reconstruction of past events is what litigation is all about. Even the simplest rule of law may produce a victor with a bare "preponderance of evidence" on its side.

Perhaps, though, Jerry Markham is correct in arguing that manipulation will remain an "unprosecutable crime" so long as adjudicators must determine after the fact just why the market price jumped, and that it is better to rely on more comprehensive preventive regulation. ${ }^{59}$ I am reluctant to reach that conclusion, however, because, as Markham recognizes, such regulation carries its own costs..$^{60}$ I prefer to hope, until hope appears vain, that the apparent intractability in manipulation litigation does not inhere in the subject but results from a failure to understand it. Asking the right questions, ones that accurately describe the phenomenon at issue, will make the factfinder's task easier, and in any event far more rational. A squeeze cannot be described adequately by a checklist of criteria, as under the classical approach. The essence of a squeeze is the exploitation of power over the shorts, and the source of that power is the shorts' vulnerability to the sanctions imposed for default.

59. Markham, supra note 1 , at 88-90.

60. Id. at 89. 


\section{APPENDIX}

This Appendix examines the economics of an alleged futures squeeze, showing how radically different accounts might explain extremely high prices. To set the scene, it will help first to examine a market without futures contracts. Assume that Long controls a large share of the supply of stringbeans, that what constitutes the supply is unambiguous, and that Long has no use for the beans except to sell them on this market. Assume also that no other individual actor accounts for a significant share of the physical supply or demand.

In Figure 1, line $\mathbf{D}$ represents the total industry demand at a given price. The effective demand facing Long is less, however, for at any given price small competitors will supply some beans. Line $\mathbf{D}_{\mathbf{L}}$ represents this effective demand; the horizontal gap between $\mathbf{D}$ and $\mathbf{D}_{\mathrm{L}}$ indicates, for any given price, the quantity that the small competitors will supply. Line $\mathbf{M C}_{\mathbf{L}}$ is Long's marginal cost curve. If Long acted like any of the other suppliers, producing until his marginal cost equaled the market price, equilibrium would be reached at the price and quantity indicated by point $C$ : At price $O A$, Long would produce the quantity $A B$ and the small competitors would produce the quantity $B C$, and consumers would demand just the total of those two amounts, $A C$.

But Long will not act like the other suppliers, because he will realize that increasing his production significantly will lower the price. Thus, for any given output by Long, his marginal revenue, indicated by line $\mathbf{M R}_{\mathbf{L}}$, is lower than the market price. Long will produce until marginal revenue equals marginal cost. That will occur when he makes the quantity $D E$, which he can sell at the price $O D$. At that price, the small competitors will supply the quantity $E F$. And at that price, consumers will be willing to buy the entire industry's output, $D F$.

Now we will alter the assumptions somewhat. First, assume that futures are traded on this simple market and that Long has bought a very large long futures position; we need not be concerned with how much he paid for the contracts. ${ }^{61}$ For simplicity, assume that Long is the only trader now holding a long futures position and that - perhaps in anticipation of a likely run-up in the price - no one else is now willing to go short. Finally, suppose that prices have reached a level significantly higher than $O D$.

We will examine two polar-opposite scenarios that might lead to such a price. Section A will look at Long's version, which places no importance on the availability of futures trading and instead emphasizes Long's own use for the physical product. Section B will examine the account of an aggressively litigating party claiming that Long squeezed the market.

61. I do not mean to suggest that the intention with which, or the price at which, a trader acquired his long position has no evidentiary significance in determining whether a squeeze occurred. A long might, for instance, be able to argue with some force that he bought most of his contracts at such elevated prices that an attempted squeeze would have been foolhardy, and that only a genuine perceived need to own the commodity could explain his conduct. On the other hand, if a trader has previously acquired a large long position, then increasing that position after learning of market congestion might be considered evidence of manipulative intent. See note 16 supra. 


\section{Figure 1}

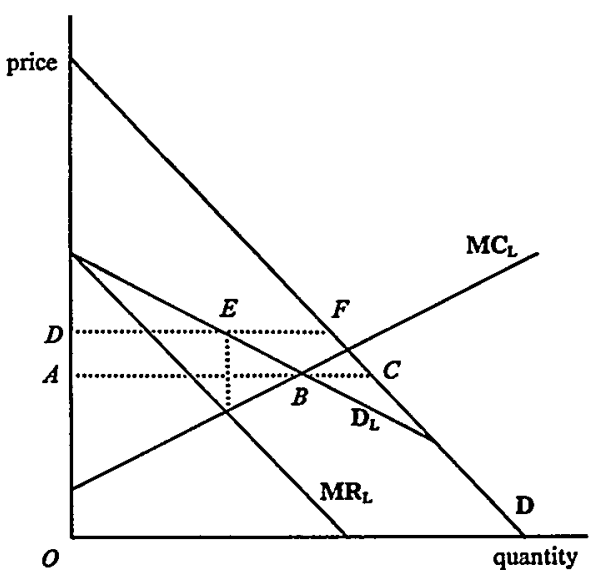

\section{A. The Defendant's Account}

Long will assert that, in driving the market to a price higher than $O D$, he was acting like any other large-scale market actor. He may offer Figure 2 as an accurate representation of what happened. This diagram does not reflect the open futures interest in any way, for Long will contend that, at most, futures trading provided a mechanism for facilitating ordinary transactions in physicals. Rather, Figure 2 is similar to Figure 1, but with a new marginal cost curve, $\mathbf{M C}_{\mathbf{L}}{ }^{\prime}$. For any given marginal cost, this curve indicates less output than does $\mathbf{M C}_{\mathbf{L}}$. The difference, Long may assert, reflects his own use for the commodity; the lower the marginal cost, the more he can use. Thus, $\mathbf{M C}_{\mathbf{L}}{ }^{\prime}$ represents a net marginal cost curve: For any given marginal cost, $\mathbf{M C}_{\mathbf{L}}$ indicates the total amount Long can produce, the gap between $\mathbf{M C} \mathbf{C}_{\mathrm{L}}$ and $\mathbf{M C}_{\mathbf{L}}{ }^{\prime}$ indicates his own use of the product, and $\mathbf{M} \mathbf{C}_{\mathbf{L}}{ }^{\prime}$ indicates the net amount he can make available to the market. 
FIGURE 2

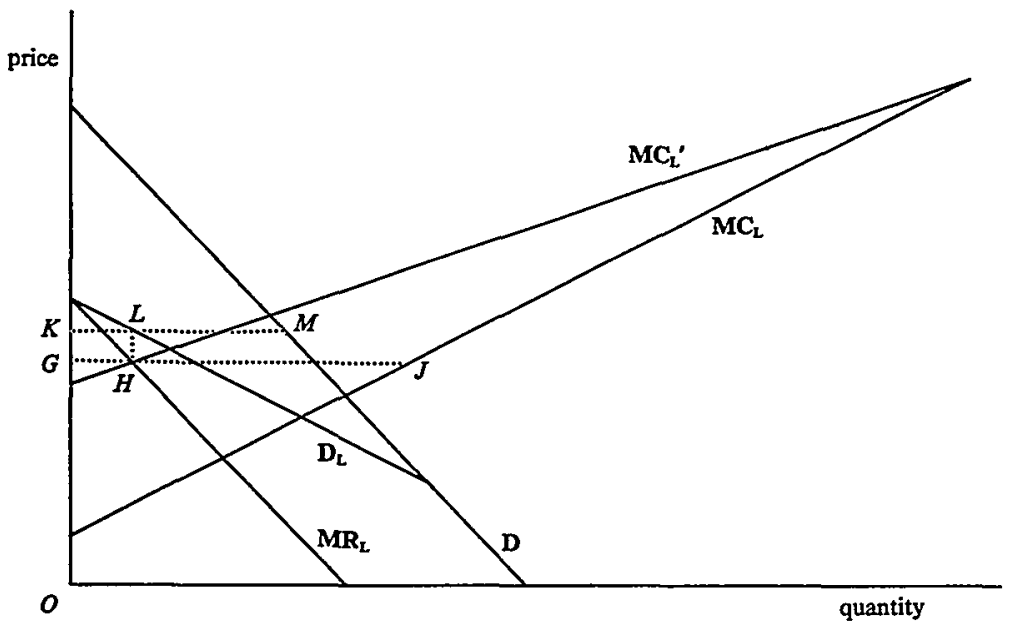

Given this curve, Long's profit-maximizing conduct would lead to a price of $O K$ - considerably above $O D$ - without his ever having thought of the shorts or their vulnerability to sanctions. At that price small competitors would supply $L M$ to the market and Long would supply $K L$ (equal to $G H$ ). But Long would also produce $H J$ for his own use; $G J$, the sum of $G H$ and $H J$, is the most he could produce without raising his marginal cost, and at that marginal cost $H J$ is the largest amount that would be worthwhile for him to use himself.

\section{Figure 3}

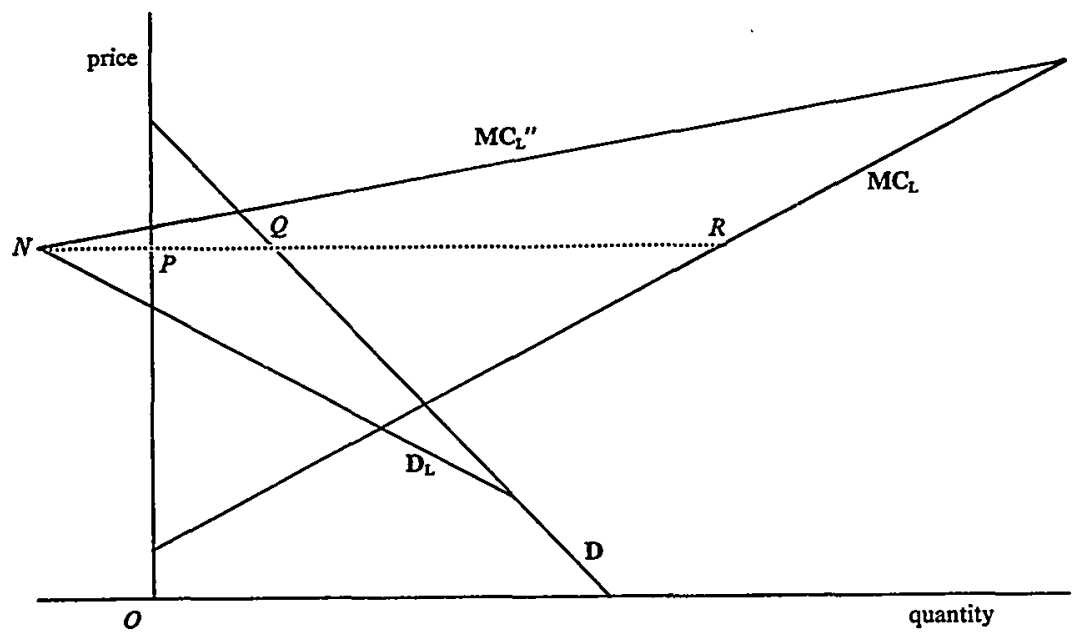


Even much higher prices could be explained by a similar account; the greater we assume Long's own use for the product is, the higher his profitmaximizing price is. Suppose that, even after using all he can produce at marginal cost no higher than the market price, it is still worth Long's while to pay that price for more. Long, in other words, may become a net demander of the product. Figure 3 shows how this may occur. Here, Long's net marginal cost curve is $\mathbf{M C}^{\prime \prime}$. Where this line extends to the left of the vertical axis, it indicates that Long will want to be a net buyer. As $\mathbf{M C}_{\mathbf{L}}{ }^{\prime \prime}$ is drawn, Long has such great use for the beans that this will occur even at relatively high prices. And of course at high prices, the small competitors will produce more than other consumers want to buy. This suggests that equilibrium will be reached at price $O P$. That price would result in small competitors producing $N Q$ with Long removing $N P$ from the market and the balance, $P Q$ being sold to other consumers. But, according to this account, at that price Long would also find it worthwhile to produce $P R$ for his own use, in addition to the amount he bought. ${ }^{62}$ Standing for delivery on futures contracts, according to Long, is merely the method by which he effectuates some of the purchases.

According to Long, high prices are explained by the ordinary forces of supply and demand; he will argue that his own demand for the product contributes upward price pressure, and he might acknowledge that his control of a large portion of the supply does as well. But in his view, the vulnerability of the shorts to default does not affect prices.

\section{B. The Claimant's Account}

The aggressively litigating claimant presents a far different view of how the price and output results in either Figure 2 or 3 might be reached. She argues that in fact Long has no use for the commodity except to sell it on this market. Rather, she contends, the critical fact is that Long has a large long futures position. This position corresponds to an equivalent short open interest, which is indicated in Figure 4 by shifting the effective demand curve facing Long rightward by the amount of the open interest, to $\mathbf{D}_{\mathbf{L}}{ }^{\prime} . \mathbf{D}_{\mathrm{L}}{ }^{\prime}$ is exactly parallel to $D_{L}$; this is because the shorts must avoid default by purchasing physical supply or offsetting contracts, even if the price rises very high, and so their demand is inelastic.

Long could sell at price $O D$, the price that maximized his profits before futures trading was introduced to the market. At that price, consumers would continue to buy $D F$ and the small competitors to produce $E F$, leaving Long to sell $D E$. The shorts would then effectively liquidate their contracts, $E S$ in quantity, at the market price, $O D{ }^{63}$ But Long is forgoing potential

62. The actual amounts and prices might be slightly different given these curves if Long, recognizing that size gave him buying power, sought the intersection of $\mathbf{M C}_{\mathbf{L}}{ }^{\prime \prime}$ with an extension of $M R_{L}$ rather than that with $D_{L}$. The essential analysis would not change; in any event, if necessary Long could hypothesize another net marginal cost curve that would account for price OP.

63. Most of the shorts would liquidate by offset at the market price. Some might actually deliver, by procuring some of the physical supply that small competitors would otherwise have sold to consumers. (Or in fact a short might be one of the small producers, and so use part of her product for delivery rather than for sale to customers.) But then Long could take that delivered product and sell it, at the same price, to the same consumers; the effect would be the same as if the short had offset at the market price. 
profits if he does not press the price at least somewhat higher.

For example, suppose he picked a price of $O K$ (the same price that Long would explain with Figure 2). To do this, he would have to sell a much smaller amount, $K L$ : The higher price reduces consumers' demand to $K M$ and increases the small competitors' output to $L M$, thus leaving a much narrower gap for Long to fill. But the shorts would still need effectively to offset all their contracts, $L T$, at the market price. And because the market price is now so much higher, this might be a profitable strategy for Long to pursue.

Indeed, he might well pursue it even further. If he pressed the price to $O U$, the small competitors would supply just the amount that consumers would buy. Thus, Long would supply no physical product to the market at all, but he would still be able to liquidate his entire futures position at the going price.

If Long lets price rise even higher than $O U$, the small competitors will be eager to sell more than consumers will want to buy; thus, above price $O U, \mathbf{D}^{\prime}$ is left of the vertical axis. For example, suppose that Long lets the price rise to $O P$. This is the price that would be explained in Long's account by Figure 3. According to Figure 4, as in Long's account, other suppliers will want to sell $N Q$ but consumers will only want to buy $P Q$. This means that Long can maintain the price only by becoming a net buyer; although he is potentially a low-cost supplier to the market, he must remove from the market quantity $N P$ supplied at high cost by others. He can do this by accepting delivery on that quantity of futures contracts; the remainder, $P V$, will be liquidated at price $O P$. That price may be high enough to make this strategy appealing. It will not only reduce the number of contracts that Long offsets, however, but it will also leave him with the problem of how to "bury the corpse" - that is, how to dispose of the product on which he had to take delivery to maintain price so high. ${ }^{64}$ And if Long is tempted to press price even higher, he must realize that he can do so only by increasing the size of the corpse that requires burial.

64. 3 P. Johnson \& T. HAZEN, Commodities Regulation $\$ 5.27$ at 53 (1987); T. Russo, supra note $3, \S 12.13$. 


\section{FIGURE 4}

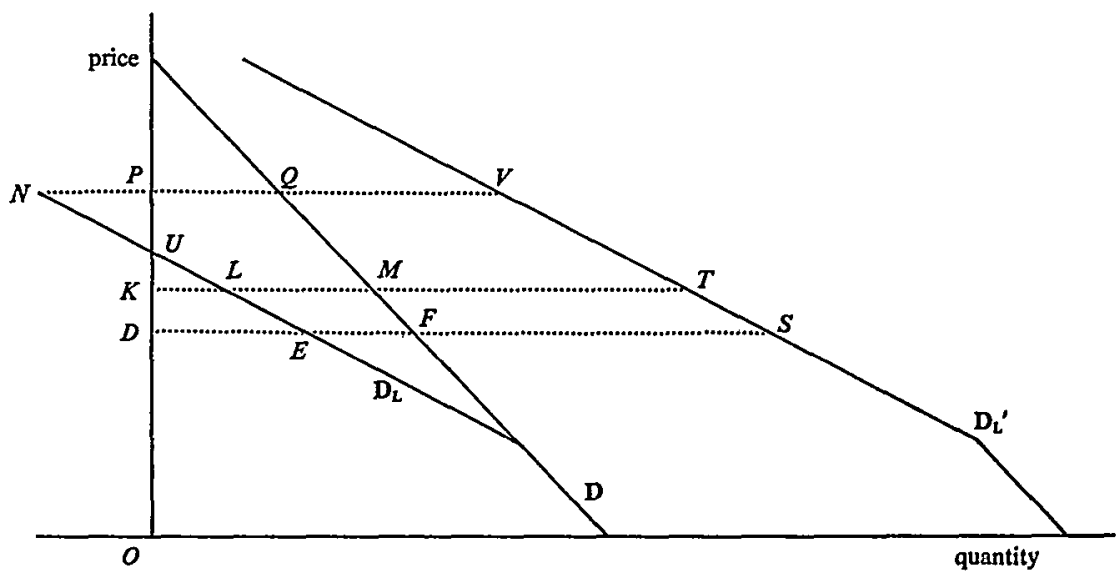

At just what price is Long's total profit maximized? The availability of profits from the sale of futures contracts, which steadily increase until price reaches $O M$, indicates that the profit-maximizing price must be at least slightly higher than $O D$, which was Long's optimal price without taking those profits into consideration. And the profit-maximizing price may even be considerably higher than $O U$. Just where it will be depends on various factors. Let us focus on four:

\section{How Much Additional Product Can Others Supply at High Prices?}

Imagine that the gap between $\mathbf{D}$ and $\mathbf{D}_{\mathbf{L}}$ narrowed - that is, for any given price, the small competitors could supply less commodity than before. This would mean that, as compared with the previous situation, more shorts would offset and fewer would deliver in the face of a price rise. Thus, the less supply other actors can provide, the more liquidation profits a price rise will offer and the less intimidating a corpse it will threaten.

Of course, Long might have limited the ability of other suppliers to respond to a price rise, and so increased his control over the market, by buying up a substantial portion of their supply or productive capacity. Depending on the size of Long's futures position, among other things, such purchases might even be necessary if he is to have any hope of squeezing the market. But possession by Long himself of a large amount of supply is not an absolute precondition to a squeeze. Given a particular shape of $D$ and $D_{L}$, it may matter relatively little how much physical supply Long controls beforehand, or how cheaply he can produce it. Indeed, if the price rises above $O U$, Long is a net buyer, and so he will not have to introduce any additional product to the market at all.

\section{How Much Product Will Buyers Demand at High Prices?}

The more product that buyers are willing to purchase at a given price, the less will be available for delivery against futures contracts. That means that fewer of the shorts will deliver and more will liquidate - again yielding a 
smaller corpse and greater liquidation profits. The stronger the buyer demand, therefore, the greater is Long's ability to control the market.

\section{How Large a Futures Position Does Long Have?}

If Long's futures position is tiny, then it will not offer him very much opportunity to make litigation profits, and his total profits will be maximized near $O D$, the price that maximizes his profits from the sale of physicals. If, on the other hand, his futures position is enormous, then there are many shorts whom he can exploit by driving price higher. His total profits will therefore likely be maximized at a much higher point. In sum, the larger Long's futures position, the greater is his incentive to drive the market to a higher price.

\section{How Valuable Is the Corpse?}

If any product accepted by Long will be worthless to him - if, for example, to keep the price high he may not attempt to sell the beans he has accepted until they spoil - his incentive to press prices higher will be dampened. But perhaps the beans have some durable value to him; if so, he will be more willing to accept the large deliveries that a high price will yield.

Suppose, for example, that Long can later unload whatever product he accepts at the price that buyers would now pay for the total amount produced. ${ }^{65}$ Under this assumption, and given the demand curves in Figure 4, $O P$ is Long's profit-maximizing price. ${ }^{66}$ This price results from a rather complex calculation: The more Long withholds from the market now, the higher

65. The supposition is indicated in Figure 4n. If the actual price is $O P$, so that the total amount produced is $N Q$ draw $P W$ so that $P W$ equals $N Q$ in length. Drop a vertical line from $W$ to $D$. The intersection, at $X$, indicates the price, $O Y$, that consumers would pay for $N Q$. The value to Long of the NP corpse, under the supposition stated in the text, is therefore the area of the rectangle $O Y Z Z$ :

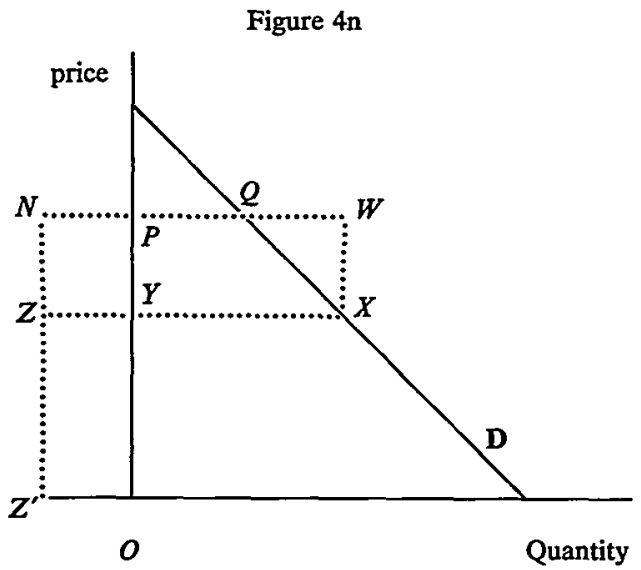

66. Long's profit is maximized when he maximizes his incremental net revenue (that is, profit calculated without regard to the price he paid for his futures contracts, which is sunk cost). For a price below $O U$, Long's incremental net revenue equals the market price times the sum of the physical amount he sells and the outstanding futures interest, all less the cost to Long of producing the physical amount he sells. For a price greater than $O M$, his incremental net revenue equals the value of the corpse plus the product of the market price and the amount of the short 
the price at which he will be able to offset futures contracts, but the fewer the number of contracts he will be able to offset, the larger the corpse he will later have to bury, and the lower the unit price he will be able to get for the corpse.

This analysis suggests that the squeezer makes a profit-maximizing calculation in the ordinary sense; ${ }^{67}$ the trouble is that a factor in the calculation is the inelastic portion of the demand, not related to the economic value of the commodity but rather driven by the shorts' need to satisfy their legal obligations.

interest effectively offset at that price. If price is $O P$, for example, the value of the corpse is the area described in note 65 supra, and the amount of the short interest effectively offset is $P V$.

67. This might not hold true for the trader who buys his futures position with the intent of creating a squeeze. But, as argued in Part I of the text, such an early intent is not necessary for a squeeze, cf. supra notes 16,61 ; the essence of the squeeze is the decision to retain one's position as the contract nears expiration. 